\title{
O CARÁTER OBJETIVO DO PROCESSO BRASILEIRO NO CONTROLE JUDICIAL DE CONSTITUCIONALIDADE: ESTUDO DE SUA DIMENSÃO E DE SUA COMPATIBILIZAÇÃO COM AS regras do Direito Processual CiviL
}

Tese apresentada à Banca Examinadora da Faculdade de Direito da Universidade de São Paulo, como exigência parcial para a obtenção do título de Doutor em Direito Processual, sob orientação do Prof. Dr. Oreste Nestor de Souza Laspro.

Versão corrigida e apresentada nos termos da Resolução CoPGr No 6018, de 13 de outubro de 2011. $O$ exemplar original encontra-se disponivel na Biblioteca da Faculdade de Direito da USP e na Biblioteca Digital de Teses e Dissertações da USP (BDTD).

\section{FACULDADE DE DIREITO DA USP \\ São Paulo




\section{RESUMO}

PIGNATARI, A. A. C. G. O caráter objetivo do processo brasileiro no controle judicial de constitucionalidade: estudo de sua dimensão e de sua compatibilização com as regras do direito processual civil. 2014. 299 f. Tese (Doutorado) - Faculdade de Direito, Universidade de São Paulo, São Paulo, 2014.

A presente tese se ocupa do processo em que o órgão judicial realiza o controle de constitucionalidade de normas ou de omissões normativas. Mais precisamente, a investigação recai sobre a índole ou natureza objetiva de que se reveste tal processo no sistema pátrio, buscando-se: (i) analisar a sua real dimensão ( $o$ que, como e em que medida o mencionado caráter objetivo repercute na configuração estrutural e procedimental daquele processo); (ii) identificar o conjunto normativo processual e concepções da dogmática processual civil que se compatibilizam nesse quadrante (até mesmo porque, a esse respeito, muitas são as polêmicas no ambiente doutrinário e muitas são as dúvidas surgidas em razão de uma nãouniformidade de pronunciamentos do Supremo Tribunal Federal). A hipótese do trabalho reside na seguinte ideia: o caráter objetivo do processo não se restringe ao controle abstrato de constitucionalidade e se harmoniza, ainda que com limites, com as regras do direito processual civil brasileiro. Desse modo, o estudo se inicia com um exame de premissas conceituais, classificatórias e terminológicas que tangenciam os domínios da jurisdição constitucional; nessa parte da pesquisa, também são colhidos subsídios aptos para consolidar a noção de que o caráter objetivo pode se apresentar com maior ou menor expressão em toda atividade jurisdicional. Para compreender como a natureza objetiva em estudo se afirma no sistema jurídico atual, parte-se para uma análise de seus aspectos históricos e conceituais, prosseguindo-se com um exame que confere ênfase ao exercício do controle principal e abstrato - modalidade que viabiliza em maior escala a projeção da natureza objetiva do processo. Nesse contexto, inclusive, enfrentam-se questões processuais relacionadas à existência - ou não - de lide, partes, contraditório, cognição judicial sobre fatos e de atividade probatória, rompendo-se mitos que doutrina e jurisprudência chegaram a estabelecer sobre esses assuntos. Para a demonstração de que o caráter objetivo também se apresenta no controle difuso e concreto, embora com menor projeção, realiza-se uma abordagem sob a ótica da tutela jurisdicional coletiva; posteriormente, o foco se volta para o fenômeno da expansão de caracteres da natureza objetiva para as vias processuais vocacionadas à proteção de interesses subjetivos. Considerações conclusivas - de cunho crítico - encerram o trabalho. Pondera-se, sobretudo, que a natureza objetiva conduz a uma modelagem processual de feição diferenciada, mas que, ao mesmo tempo, contempla padrões que não se desvencilham das vigas mestras e dos institutos fundamentais do direito processual civil.

Palavras-chave: Jurisdição constitucional. Processo constitucional. Controle de constitucionalidade. Direito processual constitucional. Processo objetivo. Litigância de interesse público. Processo coletivo. "Objetivação". 


\begin{abstract}
PIGNATARI, A. A. C. G. The objective character of the brazilian process in judicial control of constitutionality: a study of its dimension and compatability with civil procedural law. 299 f. Tese (Doutorado) - Faculdade de Direito, Universidade de São Paulo, São Paulo, 2014.
\end{abstract}

The focus of this thesis is the process by which a judicial body carries out the constitutional control of rules or the omission of regulatory groups. The research more specifically deals with the character or objective nature with which this process is covered in the national system. The aim of the work is to (i) analyse its real dimension (what, how and to what extent the aforementioned objective character affects the structural and procedural setting of the process); (ii) identify the procedural set of rules and dogmatic civil procedural conceptions that are compatible in the area (because there are many controversial issues in such regard in the doctrinal environment and many doubts have arisen due to non-uniform Supreme Court pronouncements). The hypothesis of this work rests in the following idea: the objective character of the process is not restricted to the abstract control of constitutionality. It is rather in harmony, under certain limits, with the rules of Brazilian civil procedural law. The study therefore starts with an examination of conceptual, terminological and classificatory assumptions that constitute the constitutional jurisdiction fields. State support is also chosen in this part of the research to consolidate the idea that objective character is expressed in different levels across all jurisdictional activity. An historical and conceptual analysis is conducted in order to understand better how objective nature in study is present in the current legal system. The emphasis of the examination is on the exercise of principle and abstract control, which allows for a greater scale projection of the objective nature of the process. In this context, the thesis also encompasses procedural questions dealing with leads, parts and contradiction and judicial cognition about facts and evidential activity. Myths that doctrine and case law have established on these matters are thereby broken. In order to demonstrate that objective character is also present in the diffuse control, albeit with less projection, the perspective of collective legal protection is focused on and in turn moves on to the phenomenon of character expansion of objective nature of the procedures that are directed at the protection of subjective interests. Concluding considerations of a critical nature complete the work. It is, in sum, a reflection that objective nature does shape procedural features, but at the same time is unable to affect the structure of the fundamental institutions of civil procedural law.

Keywords: Constitutional jurisdiction (judicial review). Constitutional process, control of constitutionality. Constitutional procedural law. "Objective process". Litigation of public interest. Collective process (class action). "Objectification" (objective analysis). 


\section{RIASSUNTO}

PIGNATARI, A. A. C. G. Il carattere obiettivo del processo brasiliano nel controllo giudiziale di costituzionalità: studio della sua dimensione e della sua compatibilizzazione con le regole del diritto processuale civile. 299 f. Tese (Doutorado) - Faculdade de Direito, Universidade de São Paulo, São Paulo, 2014.

La seguente tesi si occupa del processo nel quale l'organo giudiziale realizza il controllo di costituzionalità di norme o di omissioni normative. Più precisamente, l'investigazione recade sull'indole o sulla natura obiettiva con la quale si riveste tale processo nel sistema giuridico brasiliano, cercando di: (i) analizzare la sua reale dimensione (quello che, come e in quale misura il citato carattere obiettivo ripercuote nella configurazione strutturale e procedurale di quel processo); (b) indentificare l'insieme normativo processuale e le concezioni della dogmatica processuale civile che si compatibilizzano in questo quadro (soprattutto perché su questo argomento sono molte le polemiche nell'ambiente dottrinario e molti sono i dubbi sorti in relazione ad una non-uniformità dei discorsi del Supremo Tribunale Federale). L'ipotesi del lavoro risiede nella seguente idea: il carattere obiettivo del processo non si restringe al controllo astratto della costituzionalità e si armonizza, anche se con limiti, con le regole del diritto processuale civile brasiliano. In questo modo, lo studio inizia con un esame di premesse concettuali, classificatorie e terminologiche che lambiscono i domini della giustizia costituzionale; in questa parte della ricerca, sono anche raccolti sussidi adatti a consolidare la nozione che il carattere obiettivo si può presentare con una maggiore o minore espressione in tutta l'attività giurisdizionale. Per comprendere come la natura obiettiva in studio si afferma nel sistema giuridico attuale, si parte da un'analisi dei suoi aspetti storici e concettuali, proseguendo con un esame che conferisce enfasi all'esercizio del controllo principale e astratto - modalità che viabilizza in maggior scala la proiezione della natura obiettiva del processo. Inoltre, in questo contesto, si affrontano questioni processuali relazionate all'esistenza - o no - di lite, parti, contradditorio, cognizione giudiziale su fatti e di attività probatoria, rompendosi così miti che la dottrina e la giurisprudenza sono arrivati a stabilire su questi argomenti. Con la dimostrazione che il carattere obiettivo si presenta anche nel controllo diffuso e concreto, anche se con minore proiezione, si realizza un approccio sotto l'ottica della tutela guirisdizionale collettiva; successivamente, l'attenzione si concentra al fenomeno dell'espansione dei caratteri della natura obiettiva alle vie processuali, con vocazione alla protezione degli interessi soggettivi. Le considerazioni finali - di stampo critico - concludono il lavoro. Si esamina, soprattutto che, la natura obiettiva conduce ad un modello processuale di aspetto differenziato, ma che, allo stesso tempo, contempla forme che non si svincolano dalle colonne portanti e dalle norme fondamentali del diritto processuale civile.

Parole-chiavi: Giustizia costituzionale. Processo costituzionale. Controllo di costituzionalità. Diritto processuale costituzionale. "Processo obiettivo" ("processo a contenuto oggettivo"). Contesa di interesse pubblico. Processo collettivo. "Obiettivazione". 


\section{CAPÍTULO I - INTRODUÇÃO}

\subsection{Apresentação, justificativa e importância da tese}

A presente tese se ocupa do processo pelo qual o órgão judicial realiza o controle de constitucionalidade de normas ou de omissões normativas. Mas não se trata de estudar, aqui, todo e qualquer aspecto seu, mas sim e tão somente o caráter objetivo de que se reveste no sistema jurídico pátrio.

Para dizer o mínimo, o tema é permeado de complexidades.

A começar pelo contexto em que se insere, o assunto figura no âmbito da jurisdição constitucional, cuja nota marcante, por sua vez, é a multiplicidade de incoerências no campo terminológico ${ }^{1}$ e de divergências outras (que vão do "zero ao infinito"). ${ }^{2}$

Ademais, conquanto inegavelmente já apreciado em âmbito nacional e estrangeiro, o caráter objetivo do processo do controle de constitucionalidade apresenta contornos conceituais imprecisos e diversos aspectos inexplorados; tanto assim, que autorizadas vozes conclamam a necessidade de se produzirem mais estudos acadêmicos com proposições de adequada sistematização do assunto. $^{3}$

E não apenas isso: é corrente o entendimento de que tal caráter objetivo seria um atributo exclusivo do processo em que o órgão judicial exerce a verificação abstrata de normas e omissões, resultando em uma configuração procedimental diferenciada dos mecanismos processuais "comuns" ou "tradicionais". ${ }^{4}$ Em nosso país, contudo, marcado por um sistema eclético de controle, ${ }^{5}$ apontamentos mais recentes sustentam a presença de

1 Entre outros, conferem destaque a tal preocupação: José Afonso da Silva. El proceso constitucional. In: BUZÁN, Victor (Coord.). Defensa de la constitución. garantismo y controles. Libro en reconocimento al Doctor Germán J. Bidart Campos. Buenos Aires: Ediar, 2003, p. 753; Ivo Dantas. Novo processo constitucional brasileiro. Curitiba: Juruá, 2010, p. 55. Pensa assim, na doutrina estrangeira: Domingo Garcia Belaunde. Encontros e desencontros em relação ao direito processual constitucional. Revista Brasileira de Estudos Constitucionais, a. 1, n. 4, Belo Horizonte, out./dez. 2007, especialmente p. 35.

2 A metáfora é empregada por José Jesus Cazetta Jr. A ineficácia do precedente no sistema brasileiro de jurisdição constitucional (1891-1993): contribuição ao estudo do efeito vinculante. 2004. Tese (Doutorado em Direito Processual Civil)- Faculdade de Direito, Universidade de São Paulo, São Paulo, 2004, p. 4.

3 Assim parece se posicionar André Ramos Tavares. Processo "objetivo" como processo aberto ao concreto. Revista Brasileira de Estudos Constitucionais - RBEC, Belo Horizonte, n. 4, 2011, p. 16-17.

4 Dão notícia dessa ordem de pensamento, na doutrina lusitana, José Joaquim Gomes Canotilho. Direito constitucional e teoria da Constituição. Coimbra: Almedina, 2003, p. 900 e ss. Na literatura pátria, André Ramos Tavares e Renato Gugliano Herani constatam a existência desse modo de pensar. Vide, respectivamente: Processo "objetivo" como processo aberto ao concreto, op. cit., p. 13; 17 e ss.; e Controle de constitucionalidade de leis pré-constitucionais. São Paulo: Método, 2010, p. 241.

5 Cf. José Carlos Barbosa Moreira. Comentários ao código de processo civil. Vol. 5. Rio de Janeiro: Forense, 2006, p. 31. Aparentemente de acordo com esse rótulo, Manoel Gonçalves Ferreira Filho e José Levi Mello do Amaral 
elementos configuradores da natureza objetiva também no processo em que o controle conjuga os modelos concreto e difuso, com forte repercussão sobre o porvir da sistemática processual e constitucional vigente.

Quanto ao modelo processual de controle abstrato, díspares são as opiniões e muitas as incertezas acerca das regras processuais a serem seguidas e dos institutos fundamentais do processo que se encaixam na configuração de caráter predominantemente objetivo. ${ }^{6}$ Primeiro, porque a disciplina legal e específica sobre a matéria não oferece expressas soluções (ou, ao menos, soluções satisfatórias) para todas as questões processuais que surgem nesse palco. Segundo, porque desde a introdução de mecanismos que viabilizaram o controle concentrado em nosso ordenamento constitucional, o Supremo Tribunal Federal (STF) vem prolatando decisões que, apesar de fornecerem valorosas diretrizes processuais, nem sempre se revestem de um entendimento uniforme ou homogêneo sobre determinados aspectos. ${ }^{7}$

Diante de todo esse quadro, a hipótese do trabalho se traduz na seguinte ideia: o caráter objetivo do processo, no controle judicial de constitucionalidade brasileiro, não fica adstrito ao modelo processual de controle principal e abstrato e, embora com limites, tal caráter se harmoniza com o conjunto normativo processual civil em vigor.

Desse modo, muito mais que reconfirmar, com nova ótica, a existência de um padrão objetivo no processo brasileiro de controle judicial de normas, quer-se mostrar qual é a sua dimensão (o que, como e em que medida o mencionado caráter objetivo repercute na configuração estrutural e procedimental daquele processo), quer-se identificar o conjunto normativo processual e concepções da dogmática processual civil que se compatibilizam nesse quadrante, quer-se demonstrar, em especial, que tal natureza objetiva pode variar quantitativamente conforme o modelo de controle de constitucionalidade exercido e de acordo com a via processual eleita; querse indicar e demonstrar as implicações processuais que derivam dessas ideias.

entendem não ser correto qualificar como "híbrido" ou "misto" o controle de constitucionalidade brasileiro, pois tal modelo não "fusiona ou 'mistura' em um amálgama, controle difuso e controle concentrado. Em verdade, ambos convivem: seguem caminhos paralelos que, vez ou outra, exercem influxo recíproco" (vide Controle difuso da constitucionalidade, efeitos concretos na sentença erga omnes, análise em comparação com os efeitos da decisão proferida em ações diretas de controle da constitucionalidade. In: GAZZOLI, Maria Clara; CIANCI, Mirna; CALMON Petrônio; QUARTIERI, Rita (Coords.). Em defesa de um novo sistema de processos coletivos: estudos em homenagem a Ada Pellegrini Grinover. São Paulo: Saraiva, 2010, p. 405).

6 Com críticas a esse ambiente de dúvidas e incertezas, em razão de uma escassez normativa e metodológica a regular o tema, vide Renato Gugliano Herani. Anomia do processo constitucional objetivo. Revista de Informação Legislativa, v. 47, n. 118, out./nov. 2010, especialmente p. 210 e ss.

7 Aparentemente nesse sentido, vide Dimitri Dimoulis; Soraya Regina Gasparetto Lunardi. Curso de processo constitucional. São Paulo: Atlas, 2011, p. 223-259. 
Reconhecendo a repercussão desse caráter objetivo sobre a configuração estrutural e procedimental do processo, deseja-se evidenciar, ainda, que a dita natureza objetiva conduz a uma modelagem processual com feições diferenciadas, mas que, ao mesmo tempo, apresenta rito especial que não se desvencilha das vigas mestras e institutos fundamentais do direito processual civil; por conseguinte, é imperioso que lancemos critérios balizadores e rearticulação de conceitos para um melhor emprego das regras do direito processual civil nesse cenário.

Para tanto, o desenvolvimento do trabalho se divide em quatro etapas.

Na primeira (capítulo I), voltada ao estabelecimento de premissas conceituais, metodológicas e classificatórias, o tratamento da matéria se inicia com apontamentos gerais sobre jurisdição constitucional e a sua atual configuração no sistema brasileiro, a fim de que melhor se contextualize o cenário jurídico em que se situam os mecanismos e instrumentos processuais de feição predominantemente objetiva.

Também nesse capítulo inicial, é ponto de partida para preparar os raciocínios acerca da natureza objetiva do processo e suas repercussões: (i) o entendimento de que o direito processual constitucional ainda não se alçou à condição de segmento autônomo do direito (daí se extraem conclusões relacionadas à norma processual que se afina ao dito caráter objetivo); (ii) o contraste entre interesses subjetivos e objetivo na atividade jurisdicional e no próprio controle de constitucionalidade (como será demonstrado, as discussões antigas e novas sobre essa tensão trazem contribuições para melhor compreender o espectro de abrangência da feição objetiva do processo).

O estudo prossegue, no capítulo seguinte (o II), com uma exposição históricoevolutiva, além de um exame aprofundado sobre os elementos característicos da natureza objetiva em questão.

Não se perdeu a oportunidade de enfrentar questões controvertidas como: a natureza jurisdicional do processo de caráter objetivo (que defendemos existir, apesar de toda polêmica que carrega tal entendimento), o alcance da feição objetiva do processo sobre os diferentes métodos de controle judicial de constitucionalidade, bem como a base constitucional e infraconstitucional a dar suporte à natureza objetiva em estudo. Nessa parte da pesquisa são colhidos subsídios aptos para consolidar a noção de que o caráter objetivo pode se apresentar com maior ou menor expressão em toda atividade jurisdicional.

Aliás, é importante advertir: ao se considerar que o eclético sistema de controle de normas, em solo brasileiro, projeta diferentes potenciais e diferenciadas conclusões a depender da 
modalidade de verificação exercida (por exemplo, se de natureza concreta ou abstrata, se por via difusa ou concentrada) ${ }^{8}$ e considerando-se os apontamentos que associam a origem dessa feição objetiva à verificação abstrata, o estudo priorizou e conferiu ênfase à análise da natureza objetiva do processo no controle abstrato de constitucionalidade (capítulo III). Isso pareceu fundamental para que, depois, o foco se direcionasse a algumas particularidades dessa feição no controle concreto - modalidade que projeta a natureza objetiva em menor escala.

A propósito, não figura no rol de nossas preocupações o exame detalhado de características procedimentais das vias processuais que viabilizam o controle de normas e omissões normativas; a eventual menção a tais pontos é tangencial e feita na medida do necessário para que se compreenda o objeto de estudo.

Naturalmente, por estarmos a tratar de um processo que se volta, precipuamente, à tutela da ordem jurídica constitucional, com decisão que repercute para a toda a sociedade, a feição objetiva desse modelo pode e deve ser analisada sob a perspectiva da tutela jurisdicional coletiva, cujo modelo processual brasileiro também está preparado para trabalhar com a proteção da ordem jurídica social. Pontos de entrelaçamento e de distinções de tais processos são examinados no capítulo IV a fim de que mais adequadamente se conheça o objeto de estudo e também se verifique se seria possível transportar soluções de um modelo para outro.

A todo esse contexto cabe acrescentar que, curiosamente, o exame de questões e normas processuais acerca do controle de constitucionalidade costumou receber mais atenção de autores constitucionalistas que propriamente de processualistas; ${ }^{9}$ dessa maneira, nada obstante o inegável aprimoramento já alcançado pelo olhar atento do estudioso do direito constitucional, o tema eleito oferece, ainda e sem dúvida, uma boa gama de aspectos para o desenvolvimento de perspectivas processuais. ${ }^{10}$

Desse modo, a ausência de estudos monográficos sobre a natureza objetiva do processo (analisando, em especial, suas perspectivas conceituais e sua real dimensão no cenário brasileiro, inclusive sob a ótica da tutela jurisdicional coletiva, aliada a uma sistematização sobre

8 Cf. Ada Pellegrini Grinover. Controle da constitucionalidade. Revista de Processo, São Paulo, n. 90, abr./jun. 1998, p. 12 e ss.; José Ignácio Botelho de Mesquita. O desmantelamento do sistema brasileiro de controle de constitucionalidade. Revista do Advogado, São Paulo, n. 67, ago. 2002, p. 88 e 91.

9 Já nas décadas finais do século XX, Jesus Gonzalez Perez constatava tal quadro (Derecho procesal constitucional. Madrid: Civitas Editoriais, 1980, p. 50). Mais recentemente, também destaca esse aspecto: Domingo Garcia Belaunde. Encontros e desencontros em relação ao direito processual constitucional. op. cit., p. 35, 42.

10 Também assim para Juliano Taveira Bernardes, o qual se propôs a superar parte desse "déficit" (conforme ele mesmo definiu), oferecendo uma sistematização elucidativa sobre a incidência de alguns princípios processuais no âmbito do controle abstrato de constitucionalidade (Controle abstrato de constitucionalidade: elementos materiais e princípios processuais. São Paulo: Saraiva, 2004, p. 1; 3; 317-479). 
o emprego do conjunto normativo processual) permitirá a produção de um trabalho inovador em vários aspectos. E justamente porque os processualistas não se preocuparam em desenvolver um estudo mais aprofundado a respeito de todos os pontos acima descritos, o presente trabalho se propõe a suprir esse espaço no direito processual civil (residindo aí também uma das contribuições originais desta tese para a ciência jurídica brasileira).

Mas para além de questões nunca antes tratadas, advirta-se que a tese também busca repensar temas antigos, reavaliar premissas solidamente sedimentadas (algumas até ostentam título de "dogma" - e serão aqui contrariadas), além de chamar a atenção para alguns pontos que estavam esquecidos (como a classificação da jurisdição conforme a finalidade de tutelar direito objetivo ou direitos subjetivos) ou que não estavam claramente articulados na doutrina e na jurisprudência (tais como a aplicação de regras e princípios do processo individual no ambiente do controle abstrato). 


\section{CONSIDERAÇÕES FINAIS}

O processo, quando utilizado para o exercício do controle judicial de constitucionalidade, pode apresentar inúmeros traços que se distanciam do padrão estabelecido na sistemática legal e na dogmática processual. A distinção pode vir a ser tão expressiva, que surgem dúvidas ou controvérsias (e não são poucas) sobre a possibilidade de serem aplicadas regras da processualística tradicional naquele ambiente, ou, ainda, incertezas sobre quais delas ali se enquadram e por quê.

Nesse contexto, propôs-se, pelo presente trabalho, um particular estudo do caráter objetivo de que se reveste tal processo no sistema jurídico brasileiro.

E isso porque além de fornecer explicações sobre a configuração estrutural e procedimental diferenciada de determinados instrumentos processuais no âmbito da jurisdição constitucional, tal natureza objetiva aí se constitui como figura nuclear que reacende o debate científico sobre institutos fundamentais do processo e, a um só tempo, também norteia tendências e a construção de perspectivas para o modelo processual em que se verifica a compatibilidade de normas e de omissões normativas em face da CF.

Preocupando-se com um emprego terminológico e conceitual coerentes, esta tese inicialmente explorou aspectos que contornam o designativo "jurisdição constitucional". Desse modo, a despeito da conotação ampla que aquela locução pode assumir, o estudo canalizou seu foco tão somente sobre o processo em que se desempenha o controle judicial de constitucionalidade (uma das faces da jurisdição constitucional). Nessa parte do trabalho, as atenções também se voltaram para a adequada nomenclatura relacionada à atividade de controle de constitucionalidade e ao próprio processo em que se resolvem conflitos de natureza constitucional.

Ademais, como já de início foi asseverado, este trabalho elegeu a hipótese de que o caráter objetivo do processo não fica restrito ao controle concentrado-principal-abstrato, harmonizando-se, ainda que com limites, com o conjunto normativo processual civil em vigor.

Para a demonstração dessa assertiva, foi logo necessário delimitar a noção conceitual do dito caráter objetivo - cuja compreensão, a propósito, soa vaga no atual cenário jurídico pátrio. Com efeito, quando atrelado ao processo de controle de constitucionalidade, o rótulo "objetivo" é usualmente referido para designar a ideia de atributo representativo de 
características especiais ou um aspecto que significa o desprendimento de um interesse pessoal e direto de alguém.

Sem desprezar tais contornos e observando concepções doutrinárias (de desde o início do século XX até os dias atuais), o estudo adotou e se debruçou sobre as seguintes perspectivas (acerca da natureza objetiva ora em comento): (i) a cognição abstrata realizada sobre a norma ou uma alegada omissão normativa - pelo órgão julgador; (ii) a ausência de interesses particularizados a serem diretamente protegidos no processo; (iii) a tutela direta do interesse público; (iv) a discussão de questões políticas no ambiente judicial.

Desse modo, sem uma postura inflexível em tal sistematização conceitual, foi possível ainda concluir que todos aqueles elementos, isoladamente, não caracterizam a feição objetiva do processo, mas, a depender de quantos deles se fizerem presentes no processo, maior a intensidade do padrão objetivo ali estabelecido.

E não apenas isso: o caráter objetivo pode ser deflagrado em toda a atividade jurisdicional, com menor ou maior intensidade no processo, a depender também da natureza dos direitos e interesses diretamente tutelados naquele feito, bem como das características do sistema de controle de constitucionalidade e do respectivo sistema processual (e, por conseguinte, também da via processual) que o opera. Naturalmente, há um quadro de justificativas para tal ordem de considerações - e todas foram exploradas no capítulo II da tese, especialmente no item 2.4.

Postas, então, mais essas premissas (na verdade, desdobramentos da hipótese do trabalho), o exame do caráter objetivo do processo passou a ser bifurcado: primeiramente, foram observadas as vias processuais do controle principal e abstrato e, depois, o exercício judicial do controle difuso, incidental e concreto.

Por esse método de análise, foi possível identificar regras processuais aplicáveis às demandas da via abstrata e, sobretudo, notar a afinidade entre o caráter objetivo do processo e a dogmática processual civil. Mesmo diante da necessidade de explorarmos a rearticulação de conceitos e até mudanças de perspectivas no enfrentamento de algumas questões processuais, os postulados da teoria geral do processo, construções do direito processual civil e regras do CPC serviram de parâmetro. Ilustram isso: a análise realizada sobre a atividade jurisdicional e a existência de "lide", bem como o estudo sobre sujeitos processuais, contraditório, cognição judicial sobre fatos e atividade probatória, rompendo-se mitos que doutrina e jurisprudência chegaram a estabelecer sobre esses assuntos. 
De todo modo, colhem-se dos julgados do STF e também da doutrina que a dita compatibilidade (entre as regras da processualística tradicional e o processo de controle abstrato): (i) não se afigura quando a ratio da norma do CPC residir justamente no específico interesse jurídico do litigante ou interveniente (ou quando tal interesse figurar em primeiro plano); (ii) existe quando a norma do CPC contemplar interesse público em caráter exclusivo ou preponderante sobre aquele específico (particular ou subjetivo).

Partindo-se para a demonstração de que o caráter objetivo também se apresenta no controle difuso e concreto (embora com menor projeção, vale reforçar), o estudo passou para uma abordagem:

(a) sob a ótica da tutela jurisdicional coletiva, tendo-se, ao final, constatado que, a despeito de pontos comuns entre as ações coletivas lato sensu (que viabilizam o exercício do controle concreto) e as demandas de controle abstrato, não há a mesma intensidade de caráter objetivo; nem mesmo é possível adotar soluções legais de um modelo para outro, face à ausência de permissão legal;

(b) referente à intensificação de caracteres da natureza objetiva nas vias processuais vocacionadas à proteção de interesses subjetivos (fenômeno batizado, na doutrina e na jurisprudência, de “objetivação").

Quanto a esse último aspecto, embora não fosse o nosso intento analisar, um a um, todos os instrumentos que operam o controle difuso e concreto e nem tampouco esgotar todas as consequências ou desdobramentos que o fenômeno traz para o sistema, optou-se por identificar alguns deles. Sobreleva notar, a partir desse quadro, que além de se respaldar em contornos normativos (apontados na tese), o fenômeno propicia vantagens relacionadas à uniformização de entendimentos e segurança jurídica - com a política de valorização dos precedentes judiciais. De outra parte, sob a ótica da eficácia das decisões tomadas nesse ambiente, os riscos da "objetivação" parecem superar os benefícios, pois em nome de uma generalização, atenua-se - ilegal e inconstitucionalmente - a aplicação de regras processuais nesse ambiente. 


\section{REFERÊNCIAS BIBLIOGRÁFICAS}

ABBOUD, Georges. Jurisdição constitucional e direitos fundamentais. São Paulo: Revista dos Tribunais, 2011.

AKAOUI, Fernando Reverendo Vidal. Jurisdição constitucional e a tutela dos direitos metaindividuais. São Paulo: Verbatim, 2009.

ALESSI, Renato. Sistema Instituzionale del diritto amministrativo italiano. 3. ed. Milão: Giuffrè. 1960.

ALLORIO, Enrico. L'ordinamento giuridico nel prisma dell'accertamento giudiziale e altri studi. Milano: Casa Editrice Dott, 1957.

Problemas de derecho procesal. Tradção: Santiago Sentís Melendo. Buenos Aires: Ediciones Juridicas Europa-América, Tomo II. 1963.

ALMEIDA, Beatriz Monzillo de. A causa de pedir aberta nas ações diretas de inconstitucionalidade. Jus Navigandi, Teresina, a. 11, n. 1206, 20/10/2006 . Disponível em: <http://jus.com.br/artigos/9063>. Acesso em: 23 jan. 2014.

ALMEIDA, Gregório Assagra de. Codificação do direito processual coletivo brasileiro. Belo Horizonte: Del Rey, 2007.

. Direito processual coletivo brasileiro: um novo ramo do direito processual. São Paulo: Saraiva, 2003.

ALVIM, Eduardo Arruda. Apontamentos sobre as liminares na ação direta de inconstitucionalidade, na ação declaratória de constitucionalidade e na arguição de descumprimento de preceito fundamental. Revista Forense n.402, mar./abr. 2009.

ALVIM, José Eduardo Carreira. Direito arbitral. Rio de Janeiro: Forense, 2004.

AMARAL JÚNIOR, José Levi Mello do. Incidente de argüição de inconstitucionalidade. São Paulo: Revista dos Tribunais, 2002.

; FERREIRA FILHO, Manoel Gonçalves. Controle difuso da constitucionalidade, efeitos concretos na sentença erga omnes, análise em comparação com os efeitos da decisão proferida em ações diretas de controle da constitucionalidade. In: GAZZOLI, Maria Clara; CIANCI, Mirna; CALMON Petrônio; QUARTIERI, Rita (Coords.). Em defesa de um novo sistema de processos coletivos: estudos em homenagem a Ada Pellegrini Grinover. São Paulo: Saraiva, 2010. 
AMORIM, Aderbal Torres de. $O$ recurso extraordinário e a abstrativização do controle difuso de constitucionalidade. Revista de Processo, n. 191, jan./2011, p. 380-383.

ANDRADE, André Gustavo C. de. Dimensões da interpretação conforme a constituição. Revista de Direito do Tribunal de Justiça do Estado do Rio de Janeiro, n. 55, abr./jul. 2003

ANDRADE, José Arildo Valadão de. Objetivação do recurso extraordinário na perspectiva dos direitos fundamentais segundo os padrões de uma fundamentação substancialista de justiça constitucional. Revista de Processo, n. 198, ago. 2011, p. 61-72.

APPIO, Eduardo. A teoria da inconstitucionalidade induzida. Gênesis: Revista de Direito Processual Civil, Curitiba, n. 35, jan./mar. 2005.

APRIGLIANO, Ricardo. A ordem pública no processo civil. São Paulo: Atlas, 2011.

ARAGÓN, Manuel. Constitución y control del poder: introducción a una teoria geral del control. México: Universidad Nacional Autónoma de México, 2002.

ARAÚJO, Luciano Vianna. Pressupostos processuais. In: ZUFELATO, Camilo; YARSHELL, Flávio Luiz (Orgs.). 40 anos da teoria geral do processo no Brasil - Passado, presente e futuro. São Paulo: Malheiros Ed., 2012.

ARAÚJO, Stéfano Cunha. A tese da mutação constitucional da resolução suspensiva do Senado Federal e o processo de sufocamento do controle difuso no Brasil, após a Emenda Constitucional $n^{o}$ 45/2004. 211. Dissertação (Mestrado em Direito, Estado e Constituição)Universidade de Brasília, Brasília, 2011.

ARROYO, César Landa. Autonomía procesal del tribunal constitucional: la experiencia del Perú. In: Derecho Procesal Constitucional. Lima: Ediciones Legales, 2011, p. 373-412.

ASSIS, Araken de. Cumprimento da sentença. Rio de Janeiro: Forense, 2006.

Cumulação de ações. São Paulo: Revista dos Tribunais, 1998.

AZZONI, Clara Moreira. Recurso especial e extraordinário: aspectos gerais e efeitos. São Paulo: Atlas, 2009.

BARACHO, José Alfredo de Oliveira. Processo constitucional. Rio de Janeiro: Forense, 1984.

Teoria geral do processo constitucional. Revista de Direito Constitucional e Internacional, São Paulo, n. 62, a. 16, jan./mar. 2008. 
BARBOSA SOBRINHO, Osório Silva. Comentários à Lei 9.868/99. São Paulo: Saraiva, 2004.

BARBOSA, Andréa Carla. Direito em expectativa: tutelas de urgência e de evidência no Projeto do Novo Código de Processo Civil. Breves comentários. Revista de Processo, n. 194, abr. 2011, p. 243-276.

BARROSO, Luís Roberto. O controle de constitucionalidade no direito brasileiro. São Paulo: Saraiva, 2004.

BASTOS, Celso. Curso de direito constitucional. São Paulo: Saraiva, 1982.

BEDAQUE, José Roberto dos Santos. Direito e processo: influência do direito material sobre o processo. São Paulo: Malheiros Ed., 2006.

. Direito e processo: influência do direito material sobre o processo. São Paulo: Malheiros Ed., 2001.

Efetividade do processo e técnica processual. São Paulo: Malheiros Ed., 2006.

Nulidade processual e instrumentalidade do processo: a não intervenção do Ministério Público e a nulidade do processo. Justitia, n.150., abr./jun. 1990.

. Poderes instrutórios do juiz. São Paulo: Saraiva, 1994.

Tutela cautelar e tutela antecipada: tutelas sumárias e de urgência. São Paulo: Malheiros Ed., 2006.

BÉGUIN, Jean Claude. Le contrôle de la constitutionnalité des lois en republique federale d'Allemagne. Paris: Econômica, 1982.

BELAUNDE, Domingo Garcia. De la jurisdicción constitucional al derecho procesal constitucional. Anales de la Academia Nacional de Derecho Y Ciencias Sociales de Córdoba, tomo XXXIX. Córdoba, año acadêmico 2000-1, p. 35.

Encontros e desencontros em relação ao direito processual constitucional. Revista Brasileira de Estudos Constitucionais, Belo Horizonte, a. 1, n. 4, out./dez. 2007.

BERMUDES, Sérgio. Introdução ao Processo Civil. São Paulo: Forense, 2010.

BERNARDES, Juliano Taveira. Controle abstrato de constitucionalidade: elementos materiais e princípios processuais. São Paulo: Saraiva, 2004. 
BETTI, Emílio. Diritto processuale civile italiano. Roma: Foro Italiano, 1936.

BINENBOJM, Gustavo. A nova jurisdição constitucional brasileira. 2. ed. Rio de Janeiro: Renovar, 2004.

BISCH, Isabel da Cunha. A jurisdição constitucional e os diferentes modelos de controle de constitucionalidade. Revista da Procuradoria Geral do Estado, Porto Alegre, $\mathrm{n}^{\mathrm{o}}$ 66, v. 31, jul./dez. 2007. especialmente p. 160 e 166-167.

BITTENCOURT, Lucio. O controle jurisdicional da constitucionalidade das leis. Rio de Janeiro: Forense, 1968.

BONICIO, Marcelo José Magalhães. Proporcionalidade e processo: a garantia constitucional da proporcionalidade, a legitimação do processo civil e o controle das decisões judiciais. São Paulo: Atlas, 2006.

BONILHA, Ivan Lelis. O processo objetivo da ação direta de inconstitucionalidade. Cadernos de Direito Constitucional e Ciência Política n. 22, jan./mar. 1998.

BOULOS, Christiane. Controle preventivo jurisdicional de constitucionalidade. Critérios para a sua adoção no Brasil. 2006. Tese (Doutorado em Direito Constitucional)- Faculdade de Direito, Universidade de São Paulo, São Paulo, 2006.

BÜLLOW, Oskar Von. Teoria das exceções e dos pressupostos processuais. Tradução: Ricardo Rodrigues da Gama. Campinas: LZD, 2003.

BUENO, Cassio Scarpinella. Amicus curiae no processo civil brasileiro: um terceiro enigmático. São Paulo: Saraiva, 2006.

- Amicus curiae: uma homenagem a Athos Gusmão Carneiro. Disponível em: <http://www.scarpinellabueno.com.br>; Acesso em: 11/01/2014.

. Curso sistematizado de direito processual civil. Vol. 1. São Paulo: Saraiva, 2007.

$\frac{}{2010 .}$. Curso sistematizado de direito processual civil. Vol. 2, Tomo III. São Paulo: Saraiva,

Processo civil de interesse público: uma proposta de sistematização. in: SALLES, Carlos Alberto de (Org.). Processo civil e interesse público: o processo como instrumento de defesa social. São Paulo: Revista dos Tribunais, 2003. 
BUENO, Edgard Silveira. Amicus curiae: a democratização do debate nos processos de controle de constitucionalidade. Revista CEJ, Brasília, n. 19, out./dez. 2002.

BUJANDA, Fernando Sainz de. Lecciones de derecho financiero. Madrid: Universidad Complutense, 1982.

BULNES, Mar Jimeno. El control concentrado de constitucionalidad en España. In: BAZAN,Victor (Coord.). Desafios del control de constitucionalidad, Buenos Aires: Ediciones Ciudad Argentina, 1996.

BUZAID, Alfredo. Da ação direta de declaração de inconstitucionalidade no direito brasileiro. São Paulo: Saraiva, 1958.

CABRAL, Antonio do Passo. Nulidades no processo moderno. Rio de Janeiro: Forense, 2010.

Pelas asas de Hermes: a intervenção do amicus curiae, um terceiro especial. Revista de Processo, n. 117, 2004.

CAGGIANO, Monica Herman. A justiça constitucional: nasce uma disciplina autônoma no Brasil e no direito estrangeiro. In: CASELLA, Paulo Borba; CELLI JUNIOR, Umberto; MEIRELLES, Elizabeth de Almeida; POLIDO, Fabricio Bertini Pasquot (Orgs.). Direito internacional, humanismo e globalidade. São Paulo: Atlas, 2007.

CAIANIELLO, Vicenzo. Manuale de diritto processuale amministrativo. Torino: Utet, 1994.

CALAMANDREI, Piero. Il procedimento per la dichiarazione di illegitimità costituzionale. In: Opere Giuridiche. Vol. 3. Napoli: Morano, 1968.

Istituzione di diritto prcessuale civile. Vol. 1. Padova: Cedam, 1943.

La illegittimità costituzionale delle leggi nel processo civile. Padova: CEDAM, 1950.

CÂMARA, Alexandre Freitas. A coisa julgada no controle direto de constitucionalidade. In: SARMENTO, Daniel. O controle da constitucionalidade e a Lei 9.868/99. Rio de Janeiro: Lumen Juris, 2001.

CANAS, Vitalino. Os processos de fiscalização de constitucionalidade e da legalidade pelo tribunal constitucional: natureza e princípios estruturantes. Coimbra: Coimbra Editora, 1986.

CANELA JUNIOR, Osvaldo. A efetivação dos direitos fundamentais através do processo coletivo: o âmbito de cognição das políticas públicas pelo Poder Judiciário. 2009. Tese (Doutorado em Direito Público)- Universidade de São Paulo, São Paulo, 2009. 
CANOTILHO, José Joaquim Gomes. Direito constitucional e teoria da constituição. Coimbra: Almedina, 2003.

CANOVA, Augusto Cerino. Per la chiarezza delle idee in teme di procedimento camerale $e$ di giurisdizione volontaria. In: Sutdi in onore di Enrico Allorio. Milano: Giuffrè, 1983.

CAPONI, Remo. Autonomia del processo costituzionale: note preliminari. [s. d.] Disponível em:

<http://www.forumcostituzionale.it/site/images/stories/pdf/documenti_forum/paper/0171_cap oni.pdf.>. Acesso em: 20 nov. 2013.

CAPPELLETTI, Mauro. Apuntes para una fenomenologia de la justicia en el siglo XX. Revista de Processo, n. 71, jul./set. 1993, p. 86-87.

Juizes legisladores?. Porto Alegre: Sergio Antonio Fabris Editor, 1999.

La giustizia costituzionale delle liberta. Milano: Giuffrè, 1955.

. O controle judicial de constitucionalidade das leis no direito comparado. 2. ed. reimpr. Porto Alegre: Sergio Antonio Fabris Editor, 1999.

Repudiando Montesquieu? A expansão e a legitimidade na "justiça constitucional". Revista Forense, n. 366, mar./abr. 2003. p. 130-132.

CARDOSO, Oscar Valente. A análise de fatos pelo STF no processo do controle concentrado de constitucionalidade. Revista Dialética de Direito Processual, n. 63, jun. 2008.

CARIAS, Allan Brewer. La jurisdicción constitucional en America Latina. In: BELAUNDE, García; SEGADO, Fernandez (Coords.). La jurisdicción constitucional en Iberoamerica. Madrid: Dykinson, 1997.

CARNEIRO, Athos Gusmão. Intervenção de terceiros. São Paulo: Saraiva, 2010. Jurisdição e competência. São Paulo: Saraiva, 2001.

CARNELUTTI, Francesco. Sistema de direito processual civil. Tradução: Hiltomar Martins Oliveira. Vol. 2. São Paulo: Lemos e Cruz, 2004. Sistema de direito processual civil. Tradução: Hiltomar Martins Oliveira. Vol. 1. São Paulo: Lemos e Cruz, 2004. 
Sistema del diritto processuale civile. Vol. 2. Padova: Cedam, 1936.

CARRAZZA, Roque. Segurança jurídica e eficácia temporal das alterações jurisprudenciais. In: FERRAZ JÚNIOR, Tércio Sampaio; CARRAZZA, Roque Antonio; NERY JUNIOR, Nelson (Orgs.). Efeitos ex nunc e as decisões do STJ. Barueri: Manole, 2008, p. 68.

CARVALHO, Ludmila Lavocat Galvão Vieira de. A “causa petendi” aberta na ação direta de inconstitucionalidade e na ação declaratória de constitucionalidade no Supremo Tribunal Federal. 2002. Dissertação (Mestrado em Direito Processual Civil)- Faculdade de Direito, Universidade de São Paulo, São Paulo, 2002.

CARVAlHO, Milton Paulo de. Do pedido no processo civil. Porto Alegre: Sergio Antonio Fabris Editor, 1992.

CASTRO E CAMARGO, Maria Auxiliadora. Decretos leyes e jurisdicción. Estudios comparados. Salamanca: Ediciones Universidad de Salamanca, 2011.

CAZETTA JÚNIOR, José Jesus. A ineficácia do precedente no sistema brasileiro de jurisdição constitucional (1891-1993): contribuição ao estudo do efeito vinculante. 2004. Tese (Doutorado em Direito Processual Civil)- Faculdade de Direito, Universidade de São Paulo, São Paulo, 2004.

CERRI, Augusto. Corso di giustizia costituzionale. Milano: Giuffrè, 2007.

CHAYES, Abram. The role of the judge in public law litigation. Harvard Law Review, v. 89, mai. 1976.

CHINA, Sergio La. L'esecuzione forzata e le disposizioni generali del codice di procedura civile. Milano: Giuffrè, 1970.

CHIOVENDA, Giuseppe. Instituições de direito processual civil. Vol. 2. Tradução: J. Guimarães Menegale. São Paulo: Saraiva, 1965.

Principii di diritto processuale civile. Padova: Cedam, 1965.

CIANCI, Mirna; ALMEIDA, Gregório Assagra de. Direito processual do controle de constitucionalidade. São Paulo: Saraiva, 2011.

CICCONETTI, Stefano Maria. Lezione di giustizia costituzionale. Turim: G. Giappicheli, 2006.

CINTRA, Antônio Carlos de Araújo; GRINOVER, Ada Pellegrini; DINAMARCO, Cândido Rangel. Teoria geral do processo. 29. ed. São Paulo: Malheiros Ed., 2013. 
CLÈVE, Clèmerson Merlin. A fiscalização abstrata da constitucionalidade no direito brasileiro. São Paulo: Revista dos Tribunais, 1999.

COELHO, Inocêncio Mártires. As ideias de Peter Häberle e a abertura da interpretação constitucional no direito brasileiro. Direito Público, n. 6, out./nov. 2004.

COMELLA, Victor Ferreres. Justicia constitucional y democracia. Madrid: Centro de Estudios Politicos e Cosntitucionales, 1997.

COMOGLIO, Luigi Paolo; FERRI, Corrado; TARUFFO, Michele. Lezione sul processo civile. 2. ed. Bologna: Il mulino, 1998.

CORREIA, Marcus Orione Gonçalves. Direito processual constitucional. São Paulo: Saraiva, 1198.

CORTES, Osmar Mendes Paixão. Reclamação. A ampliação do cabimento no contexto da “objetivação" do processo nos tribunais superiores. Revista de Processo, n. 197, jul./ 2011.

COSTA, Daniel Carnio. As tutelas de urgência ex officio no processo coletivo. Tese (Doutorado em Direito)- Faculdade de Direito, Pontifícia Universidade Católica de São Paulo, São Paulo. 2013.

COSTA, Fabricio Veiga. Modelo constitucional de processo coletivo: um estudo crítico a partir da teoria das ações coletivas como ações temáticas. Revista Dialética de Direito Processual, n. 88, jul. 2010, p. 17-29.

COSTA, Susana Henriques da. $O$ controle judicial da representatividade adequada: uma análise dos sistemas norte-americano e brasileiro. In: SALLES, Carlos Alberto de (Coord.). As grandes transformações no processo civil brasileiro: homenagem ao profesor Kazuo Watanabe. São Paulo: Quartier Latin, 2009.

O processo coletivo na tutela do patrimônio público e da moralidade administrativa: ação de improbidade administrativa, ação civil pública e ação popular. São Paulo: Quartier Latin, 2009.

COUTURE, Eduardo. Fundamentos del derecho procesal civil. Buenos Aires: Depalma, n. 263, 1974, p. 411-412.

CRUZ E TUCCI, José Rogério. A causa petendi no processo civil. São Paulo: Revista dos Tribunais, 1994.

Aspectos processuais da denominada ação declaratória de constitucionalidade. In: MARTINS, Ives Gandra da Silva; MENDES, Gilmar Ferreira (Coords.). Ação declaratória de 
constitucionalidade. São Paulo: Saraiva, 1994.

Class action e mandado de segurança coletivo: diversificações conceituais. São Paulo: Saraiva, 1990.

Direito processual civil europeu contemporâneo. São Paulo: Lex Editora, 2010.

Jurisdição e poder. São Paulo: Saraiva, 1987.

Limites subjetivos da eficácia da sentença e da coisa julgada civil. São Paulo: Revista dos Tribunais, 2006.

Precedente judicial como fonte do direito. São Paulo: Revista dos Tribunais, 2004.

; TUCCI, Rogério Lauria. Constituição de 1988 e processo. São Paulo: Saraiva, 1989.

Paradoxo da Corte - Desistência do recurso não se subordina ao crivo dos tribunais. Disponível em: <http://www.idtl.com.br/noticia.cfm?ID=12667>. Acesso: 16.05.2014.

CRUZ, Gabriel Dias Marques da. Arguição de descumprimento de preceito fundamental: lineamentos básicos e revisão crítica no direito constitucional brasileiro. São Paulo: Malheiros Ed., 2011.

CUNHA JUNIOR, Dirley da. A intervenção de terceiros no processo de controle abstrato de constitucionalidade - a intervenção do particular, do co-legitimado e do amicus curiae na $A D I n, A D C$ e ADPF. In: DIDIER JUNIOR, Fredie; WAMBIER, Teresa Arruda Alvim (Coords.). Aspectos polêmicos e atuais sobre os terceiros no processo civil e assuntos afins. São Paulo: Revista dos Tribunais, 2004.

Controle de constitucionalidade: teoria e prática. Salvador: Podivm, 2006.

O principio do "stare decisis" e a decisão do Supremo Tribunal Federal no controle difuso de constitucionalidade. In: NOVELINO, Marcelo (Org.). Leituras complementares de direito constitucional. Salvador: JusPodivm, 2008.

CUNHA, Leonardo Carneiro da. A fazenda pública em juízo. São Paulo: Dialética, 2006.

D’AMICO, Marilisa. Parti e processo nella giustizia costituzionale. Torino: G. Giappichelli Editore, 1991. 
DANTAS, Ivo. Novo processo constitucional brasileiro. Curitiba: Juruá, 2010.

DANTAS, Paulo Roberto Figueiredo. Direito processual constitucional. São Paulo: Atlas, 2012.

DELFIM, Ricardo Alessi. Ação declaratória de constitucionalidade e os princípios constitucionais do PROCESSO. São Paulo: Editora Juarez de Oliveira, 2001.

DELlORE, Guilherme Pennachi. Coisa julgada, eficácia erga omnes e efeito vinculante no controle concentrado de constitucionalidade (A estabilização da decisão no controle concentrado). Tese (Doutorado em Direito Processual)- Faculdade de Direito, Universidade de São Paulo, São Paulo, 2010.

DESTEFENI, Marcos. Estabilidade, congruência e flexibilidade na tutela coletiva. 2008. Tese (Doutorado em Direito das Relações Sociais - Direitos Difusos)- Faculdade de Direito, Pontifícia Universidade Católica de São Paulo, São Paulo, 2008.

DIDIER JUNIOR, Fredie. Transformações do recurso extraordinário. Revista Forense, n. 389, jan./fev. 2007.

; BRAGA, SARNO, Paula; OLIVEIRA, Rafael. Aspectos processuais da ADIN (Ação Direta de Inconstitucionalidade) e da ADC (Ação Declaratória de Constitucionalidade). In: DIDIER JUNIOR, Fredie (Org.). Ações constitucionais. Salvador: Podivm, 2008.

; ZANETTI JUNIOR, Hermes. Curso de direito processual civil. Processo coletivo. Vol. 4. Salvador: Editora Podium, 2013.

DIMOULIS, Dimitri; LUNARDI, Soraya Regina Gasparetto. Curso de processo constitucional. São Paulo: Atlas, 2011.

DINAMARCO, Cândido Rangel. A instrumentalidade do processo. 11. ed. São Paulo: Malheiros Ed., 2005.

A instrumentalidade do processo. 15. ed. São Paulo: Malheiros Ed., 2013.

Ação direta de inconstitucionalidade: legitimidade de entes associativos, ilegitimidade da Assembléia Legislativa e Reserva de Plenário. In: Processo Civil Empresarial. São Paulo: Malheiros Ed., 2010.

Instituições de direito processual civil. São Paulo: Malheiros Ed., 2009. 
. Vocabulário do processo civil. São Paulo: Malheiros Ed., 2009.

DINIZ, Maria Helena. Compêndio de introdução à ciência do direito. São Paulo: Saraiva, 1991.

. Dicionário jurídico. 3. ed. São Paulo: Saraiva, 2008.

DITTTRICH, Lottario. Il provvedimento d'urgenza ex art. 700 C.P.C. In: TARZIA, Giuseppe (Org.). Il Processo Cautelare. 2. ed. Padova: CEDAM, 2004.

DONOSO, Denis. Aspectos processuais no controle concentrado de constitucionalidade. Coisa julgada. Objeto. legitimidade. Efeitos da medida cautelar. Aproximação dos sistemas de controle difuso e concentrado. Revista Dialética de Direito Processual, n. 60, mar. 2008.

DUTRA, Carlos Roberto de Alckmin. Controle abstrato de constitucionalidade: análise dos princípios processuais aplicáveis. São Paulo: Saraiva, 2012.

DWORKIN, Ronald. Law's Empire. Harvard University Press, 1986.

Taking rights seriously. Harvard University Press, 1978.

ELY, John Hart. Democracy and distrust: a theory of judicial review, 11. ed. Cambridge: Harvard University Press, 1995.

ENTERRÍA, Eduardo Garcia de. Hacia una nueva justicia administrativa. Madrid: Civitas, 1992

La constituición como norma y el tribunal constitucional. Madrid: Civitas, 1985.

FABRICIO, Adroaldo Furtado. Justificação teórica dos procedimentos especiais. Disponível em:

<http://www.abdpc.org.br/abdpc/artigos/Adroaldo\%20Furtado\%20Fabr\%C3\%ADcio(3)form atado.pdf >. Acesso em: 27 nov. 2013.

FALEIROS, Carolina Teodoro. A "PEC dos recursos", o projeto de novo código de processo civil e a uniformização da jurisprudência através dos recursos extraordinário e especial. Revista de Processo n. 210, ago. 2012.

FARRERES, German Fernández. El recurso de amparo según la jurisprudencia constitucional. Comentarios al Título III de la LOTC. Madrid: Marcial Pons, 1994. 
FAVOREU, Louis. As cortes constitucionais. Tradução: Dunia Marinho Silva. São Paulo: Landy, 2004.

Droit constitutionel. Paris: Dalloz, 2004.

FAZZALARI, Elio. Instituições de direito processual civil. Tradução: Elaine Nassif. Campinas: Bookseller, 2006.

Istituzioni di diritto processuale civile. 8. ed. Padova: Cedam, 1996.

FERNANDES, André Dias. Eficácia das decisões do STF em ADIN e ADC: efeito vinculante, coisa julgada erga omnes e eficácia erga omnes. São Paulo: Juspodvm, 2009.

FERRARI, Regina Maria Macedo Nery. Efeitos da declaração de inconstitucionalidade. São Paulo: Revista dos Tribunais, 2006.

FERRAZ JUNIOR, Tércio Sampaio. A ciência do direito. São Paulo: Atlas, 1980. Introdução ao estudo do direito. São Paulo: Atlas, 2003.

FERRAZ, Anna Candida da Cunha. Apontamentos sobre a jurisdição constitucional nos estados-membros. Revista de Direito da Associação dos Procuradores do Novo Estado do Rio de Janeiro, Rio de Janeiro, v. XIX, 2008.

; ALMEIDA, Fernanda Dias Menezes de. A repercussão geral e a objetivação do controle concreto. In: RAMOS, Elival da Silva; MORAIS, Carlos Blanco de (Coords.). Perspectivas de reforma da justiça constitucional em Portugal e no Brasil. Coimbra: Editora Almedina, 2012.

FERREIRA FILHO, Manoel Gonçalves. Curso de direito constitucional. São Paulo: Saraiva, 1994.

- Os princípios do processo constitucional. Revista da Faculdade de Direito da Universidade de Lisboa, n. 1 e 2, v. XLIX, 2008.

; AMARAL JÚNIOR, José Levi Mello do. Controle difuso da constitucionalidade, efeitos concretos na sentença erga omnes, análise em comparação com os efeitos da decisão proferida em ações diretas de controle da constitucionalidade. In: GAZZOLI, Maria Clara; CIANCI, Mirna; CALMON Petrônio; QUARTIERI, Rita (Coords.). Em defesa de um novo sistema de processos coletivos: estudos em homenagem a Ada Pellegrini Grinover. São Paulo: Saraiva, 2010. 
FERREIRA, Olavo Augusto Vianna Alves. Controle de constitucionalidade e seus efeitos. São Paulo: Método, 2005.

FERRI, Corrado; COMOGLIO, Luigi Paolo; TARUFFO, Michele. Lezione sul processo civile, 2 ed., Bologna: Il mulino, 1998.

FIGUEIREDO, Marcelo. Ação declaratória de inconstitucionalidade - inovação infeliz e inconstitucional. In: MENDES, Gilmar Ferreira; MARTINS, Ives Gandra da Silva (Coord.). Ação Declaratória de Constitucionalidade. São Paulo: Saraiva, 1993.

FISS, Owen. Um novo processo civil: estudos norte americanos sobre jurisdição, constituição e sociedade. Tradução: Daniel Porto Godinho da Silva; Melina de Medeiros Rós. São Paulo: Revista dos Tribunais, 2004.

FIX-ZAMUDIO, Hector. Breves reflexiones sobre la naturaleza, estructura y funciones de los organismos jurisdiccionales especializados en la resolución de procesos constitucionales. In: VEGA GÓMEZ, Juan; CORZO SOSA, Edgar (Coords.). Tribunales y Justicia Constitucional. México: Universidad Nacional Autónoma de México, 2002. Disponível em: <http://biblio.juridicas.unam.mx/libros/libro.htm?l=343>. Acesso em: 19 set. 2013.

- Veinticinco años de evolucion de la justicia constitucional. Mexico: Universidad Autónoma de México, 1968.

FLORES, Patrícia Teixeira de Rezende. Aspectos processuais da ação direta de inconstitucionalidade de lei municipal. São Paulo: Revista dos Tribunais, 2002.

FONSECA, João Francisco Naves da. Exame dos fatos nos recursos extraordinário e especial. São Paulo: Editora Saraiva, 2012.

FORÚRIA, Eduardo Vigara. Control abstracto y recurso directo de inconstitucionalidad en los Estados Unidos. Revista Española de Derecho Constitucional, Madrid, n. 62, a. 21, mai./ago. 2001.

GAJARDONI, Fernando da Fonseca. Flexibilidade procedimental (um novo enfoque para estudo do procedimento em matéria processual). 2007. Tese (Doutorado em Direito Processual)- Faculdade de Direito, Universidade de São Paulo, São Paulo, 2007.

GEIGER, Willi. Die Grenzen der bindung verfassungsgerichtlicher Entscheidungeng. In: Neue juristische Wochenschrift, Tomo II, 1952. 
GIANOZZI, Gincarlo. Riflessioni intorno all'oggetto del Processo Constituzionale. Jus, 1963.

GOLDSCHMIDT, James. Direito processual civil. Tradução: Ricardo Rodrigues Gama. Curitiba: Juruá, 2003.

GOMES, Magno Frederici; SANTOS, Daniel Lin. Da análise da desistência do recurso excepcional a partir da objetivação do processo constitucional subjetivo. Revista Brasileira de Direito Processual, Belo Horizonte, a. 20, n. 79, jul./set. 2012.

GORDO, Alfonso Perez. El tribunal constitucional y sus funciones. Barcelona: Bosch, 1982.

GRECO, Leonardo. Instituições de processo civil. Vol. I. Rio de Janeiro: Forense, 2011. 2005.

O princípio do contraditório. Revista Dialética de Direito Processual , v. 24, mar.

GRINOVER, Ada Pellegrini. Controle da constitucionalidade. Revista de Processo, n. 90, abr./jun. 1998.

Controle da constitucionalidade. Revista Forense, n. 347, abr./jun. 1998.

. Direito processual coletivo. In: ; MENDES, Aluísio Gonçalves de Castro; WATANABE, (Orgs.). Direito processual coletivo e o anteprojeto de código brasileiro de processos coletivos. São Paulo: Revista dos Tribunais, 2007, p. 11-15.

. O controle jurisdicional de políticas públicas. In: GRINOVER, Ada Pellegrini; WATANABE, Kazuo (Coords.). O Controle Jurisdicional de Políticas Públicas. Rio de Janeiro: Forense, 2011.

GUERRA FILHO, Willis Santiago. Inovações do processo na América Central: o código de processo civil e a lei da jurisdição constitucional na Costa Rica. Revista de Processo, v. 19, n. 73, jan./mar. 1994, p.67-73. 2001.

Processo constitucional e direitos fundamentais. São Paulo: Celso Bastos Editor,

HÄBERLE, Peter. El derecho procesal constitucional concretizado frente a la judicatura del Tribunal Constitucional alemán. Revista Iberoamericana de Derecho Procesal Constitucional, n. 1 , jan./jun. 2004, p. 15ss.

. Hermenêutica constitucional - A sociedade aberta aos intérpretes da constituição: 
contribuição para a interpretação pluralista e procedimental da constituição. Tradução: Gilmar Ferreira Mendes. Porto Alegre: Sergio Antonio Fabris Editor, 2002.

La verfassungsbeschwerde nel sistema della giustizia costituzionale tedesca . Tradução: Antonio D’Atena. Milano: Giuffrè, 2000.

HABERMAS, Jürgen. Direito e democracia: entre facticidade e validade. Vol. I. Tradução: Flávio Beno Siebeneichler. Rio de Janeiro: Tempo Brasileiro, 1997.

HECK, Luiz Afonso. O tribunal constitucional federal e o desenvolvimento dos princípios constitucionais: contributo para uma compreensão da jurisdição constitucional federal alemã. Porto Alegre: Sergio Antonio Fabris Editor, 1995.

HEKMAN, Glênio José Wasserstein. O cumprimento da norma do Artigo 97 da Constituição Federativa do Brasil de 1988 e a disciplina do incidente da argüição de inconstitucionalidade: uma nova perspectiva de tratamento. 2002. Tese (Doutorado em Direito do Estado)- Faculdade de Direito, Universidade de São Paulo, São Paulo, 2002.

HENNING, Fernando Alberto Correa. Ação concreta: relendo Wach e Chiovenda. Porto Alegre: Sergio Antonio Fabris, 2000.

HERANI, Renato Gugliano. Anomia do processo constitucional objetivo. Revista de Informação Legislativa, v. 47, n. 118, out./nov. 2010, p. 209-228.

Controle de constitucionalidade de leis pré-constitucionais. São Paulo: Método, 2010.

HESSE, Konrad. Elementos de direito constitucional da República Federal da Alemanha. Tradução: Luis Afonso Heck. Porto Alegre: Sergio Antonio Frabris Editor, 1998.

HITTERS, Juan Carlos. La jurisdicción constitucional en Argentina. In: BELAUNDE, García; SEGADO, Fernandez (Coords.). La jurisdicción constitucional en Iberoamerica. Madrid: Dykinson, 1997.

HORTA, Raul Machado. A autonomia do Estado-membro no direito constitucional brasileiro. Belo Horizonte: Graf. Santa Maria, 1964

Direito constitucional. 2. ed. Belo Horizonte: Del Rey, 1999.

JAUERNIG, Othmar. Zivilprozessrecht: ein Studienbuch. München: Beck, 1998. Entretanto, consultamos a obra disponibilizada em língua portuguesa (Othmar Jauernig. Direito processual civil. Tradução: Silveira Ramos. 25. ed. Coimbra: Almedina, 2002. 
KELSEN, Hans. Jurisdição constitucional. São Paulo: Martins Fontes, 2003.

La garantie jurisdictionelle de la constitution (La justice constitutionelle). Revue de Droit Public et Science Politique, n. 35, 1928, p. 197-257.

LACERDA, Galeno. Comentários ao código de processo civil. Vol. 1. Rio de Janeiro: Forense, 1999.

Despacho saneador. Porto Alegre: Sergio Antonio Fabris Editor, 1990.

LAHAV, Alexandra. Fundamental principles for class action governance. Indiana Law Review, n. 65, 2003, p. 7.

LASPRO, Oreste Nestor de Souza. A responsabilidade civil do juiz. São Paulo: Revista dos Tribunais, 2000.

Da restrição à concessão de tutelas de urgência na lei de recuperação judicial. In: YARSHELL, Flávio Luiz; PEREIRA, Guilherme Setoguti J. (Coords.). Processo societário. São Paulo: Quartier Latin, 2012. O duplo grau de jurisdição no processo civil. São Paulo: Revista dos Tribunais, 1995.

LEAL, Marcio Flávio Mafra. Ações coletivas: história, teoria e prática. Porto Alegre: Sergio Antonio Fabris, 1998.

LEAL, Roger Stiefelmann. O efeito vinculante na jurisdição constitucional. São Paulo: Saraiva, 2006.

LENZA, Pedro. Teoria geral da ação civil pública. São Paulo: Revista dos Tribunais, 2003.

LEONCY, Léo Ferreira. Controle de constitucionalidade estadual. São Paulo: Saraiva, 2007.

LEONEL, Ricardo de Barros. Causa de pedir e pedido: o direito superveniente. São Paulo: Método, 2006.

Intervenção do ministério público no incidente de resolução de demandas repetitivas. Revista Jurídica da Escola Superior do Ministério Público de São Paulo, v. 1, 2012, p. 171-185. . Manual do processo coletivo. 2. ed. São Paulo: Revista dos Tribunais, 2011. 
Reclamação constitucional. São Paulo: Revista dos Tribunais, 2012.

Recurso extraordinário e controle objetivo de constitucionalidade na justiça estadual. In: NERY JUNIOR, Nelson; WAMBIER, Teresa Arruda Alvim (Coords.). Aspectos polêmicos e atuais dos recursos cíveis e assuntos afins. São Paulo: Revista dos Tribunais, 2007.

LIEBMAN, Enrico Tullio. Manual de direito processual civil. São Paulo: Malheiros Ed., 2005.

LIMA, Fernando Antonio Negreiros. A intervenção do ministério público no processo civil brasileiro como custos legis. São Paulo: Método, 2007.

LIMA, Newton de Oliveira. Jurisdição constitucional e construção de direitos fundamentais no Brasil e nos Estados Unidos. São Paulo: MP, 2009.

LLORENTE, Francisco Rubio. Tendencias actuales de la jurisdicción constitucional en Europa. In: JIMENEZ CAMPO, Javier (Coord.). Estudios sobre jurisdicción constitucional. Madrid: McGraw-Hill, 1998.

LOPES, João Batista. Efetividade da tutela jurisidicional à luz da constitucionalização do processo civil. Revista de Processo, n. 116, jul./ago. 2004, p. 29-39.

LOPES, José Reinaldo de Lima. Direitos sociais: teoria e prática. São Paulo: Editora Método, 2006.

LOPES, Miguel Maria de Serpa. Curso de direito civil. Vol. 1. Rio de Janeiro: Livraria Freitas Bastos, 1953.

LOPES, Reinaldo Lima. Direitos sociais: teoria e prática. São Paulo: Método, 2006.

LUCON, Paulo Henrique dos Santos. Eficácia das decisões e execução provisória. São Paulo: Revista dos Tribunais, 2000.

; GABBAY, Daniela Monteiro. Superação do modelo processual rígido pelo anteprojeto do código brasileiro de processos coletivos, à luz da atividade gerencial do juiz. In: GRINOVER, Ada Pellegrini; MENDES, Aluisio Gonçalves de Castro; WATANABE, Kazuo (Coords.). Direito processual coletivo e o anteprojeto de código brasileiro de processos coletivos. São Paulo: Revista dos Tribunais, 2007, p. 78-95.

LUNARDI, Soraya Regina Gasparetto. Direito processual constitucional: problematização de sua autonomia, sua natureza e suas consequiências. 2006. Tese (Doutorado em Direito)Faculdade de Direito, Pontifícia Universidade Católica de São Paulo, São Paulo. 2006. 
. Teoria do processo constitucional: análise de sua autonomia, natureza e elementos.

São Paulo: Atlas, 2013.

LUTHER, Jörge. Il contraddittorio nei procedimenti della Normenkontrolle tedesca. In: ANGIUOLINI, Vittorio (Coord.). Il contraddittorio nel giudizio sulle leggi. Torino: G. Giappichelli, 1998.

MAC-GREGOR, Eduardo Ferrer. Direito processual constitucional: origem científica (19281956). Curitiba: Juruá Editora, 2009.

MACHADO, Hugo de Brito. Ação declaratória de constitucionalidade. In: MENDES, Gilmar Ferreira; MARTINS, Ives Gandra da Silva (Coord.). Ação Declaratória de Constitucionalidade. São Paulo: Saraiva, 1993.

MACIEL, Adhemar Ferreira. Amicus curiae: um terceiro democrático. Revista de Processo, n. 106, abr./jun. 2002.

MANCUSO, Rodolfo de Camargo. A resolução dos conflitos e a função judicial no contemporâneo Estado de Direito. São Paulo: Revista dos Tribunais, 2009.

2007.

Divergência jurisprudencial e súmula vinculante. São Paulo: Revista dos Tribunais,

Jurisdição coletiva e coisa julgada: teoria geral das ações coletivas. São Paulo:

Revista dos Tribunais, 2007.

MANDRIOLLI, Crisanto. Corso di diritto processuale civile. Vol. I. Torino: G. Giapichelli Editore, 2000.

MARCATO, Antonio Carlos. Procedimentos especiais. São Paulo: Atlas, 2007.

MARDER, Alexandre Salgado. Das invalidades no direito processual civil. São Paulo: Malheiros Ed., 2010.

MARINONI, Luiz Guilherme. Controle de constitucionalidade. In; ; SARLET; Ingo Wolfgang; MITIDIERO, Daniel. Curso de direito constitucional, 2. ed. São Paulo: Revista dos Tribunais, 2013.

Precedentes obrigatórios. São Paulo: Revista dos Tribunais, 2011, p. 461. 
civil, Vol. 5. São Paulo: Revista dos Tribunais, 2009.

MARQUES, Frederico. Instituições de direito processual civil, Vol. I. Rio de Janeiro: Forense, 1966.

Ensaio sobre a jurisdição voluntária. 1. ed. Campinas: Millenium, 2000.

Manual de direito processual civil, Vol. I. Campinas: Millennium, 2000.

MARTINS, Ives Gandra da Silva; MENDES, Gilmar Ferreira (Coords.). Ação declaratória de constitucionalidade. São Paulo: Saraiva, 1995.

; Controle concentrado de constitucionalidade: comentários à Lei $n$. 9.868, de 10-11-1999. São Paulo: Saraiva, 2009.

; __. Da eficácia das decisões do Supremo Tribunal Federal. Cadernos de Direito Tributário e Finanças Públicas, São Paulo, n. 2, jan./mar. 1993.

MARTINS, Leonardo. Direito processual constitucional alemão. São Paulo: Atlas, 2011.

MAZZEI, Rodrigo. A ação popular e o microssistema da tutela coletiva. In: GOMES JÚNIOR, Luiz Manoel (Coord.). Ação Popular - Aspectos controvertidos e relevantes - 40 anos da Lei 4717/65. São Paulo: Editora RCS, 2006.

.. Mandado de Injunção. In: DIDIER JUNIOR, Fredie (Org.). Ações constitucionais. Salvador: Podivm, 2008.

MEDEIROS, Rui. A decisão de inconstitucionalidade. Lisboa: Universidade Católica de Lisboa, 2000.

MEDINA, Damares. Amicus curiae: amigo da corte ou das partes? São Paulo: Saraiva, 2010.

MEDINA, Marcelo Borges de Mattos. Elementos para uma teoria do processo objetivo de defesa da constituição. In: FÉRES, Marcelo Andrade; M. CARVALHO, Paulo Gustavo (Coords.). Processo nos tribunais superiores. São Paulo: Saraiva, 2006.

MEDINA, Paulo Roberto de Gouvêa. Direito processual constitucional. Rio de Janeiro: Forense, 2012. 
util/print/34?print=Artigo $>$, desde 17.06.2013. Acesso em: 11 mar. 2014.

MELLO, Celso Antonio Bandeira de. Curso de direito administrativo. São Paulo: Malheiros Ed., 2006.

MENDES JUNIOR, João. Direito judiciário brasileiro. Rio de Janeiro: Freitas Bastos, 1960.

MENDES, Gilmar Ferreira. A declaração de inconstitucionalidade sem a pronúncia da nulidade como técnica da decisão da omissão legislativa parcial e o cabimento de cautelar nos casos de omissão parcial. Repertório de Jurisprudência IOB, n. 15, Caderno I, ago. 2002.

. Ação civil pública e controle de constitucionalidade. In: WALD, Arnoldo (Coord.). Aspectos polêmicos da ação civil pública. São Paulo: Saraiva, 2007. 1990.

Controle de constitucionalidade: aspectos jurídicos e políticos. São Paulo: Saraiva,

Controle de constitucionalidade: hermenêutica constitucional e revisão de fatos e prognoses legislativos pelo órgão judicial. Revista Jurídica Virtual, n. 8, vol. 1, jan./2000. Disponível em: <http://www.planalto.gov.br/ccivil_03/revista/Rev_08/cont_constitucionalidade.htm>. Acesso em: 11/01/2014.

- Direitos fundamentais e controle de constitucionalidade: estudos de direito constitucional. São Paulo: Saraiva, 2007.

Jurisdição constitucional. São Paulo: Saraiva, 2005.

2004 .

Moreira Alves e o controle de constitucionalidade no Brasil. São Paulo: Saraiva,

O papel do Senado Federal no controle da constitucionalidade: um caso clássico de mutação constitucional. Revista de Informação Legislativa, Brasília, n. 164, abr./jun. 2004, p. 149-168.

Recurso extraordinário e recurso especial. São Paulo: Revista dos Tribunais, 2006

; MARTINS, Ives Gandra da Silva. Controle concentrado de constitucionalidade: comentários à Lei n. 9.868, de 10-11-1999. São Paulo: Saraiva, 2009.

MESQUITA, José Ignacio Botelho de. O desmantelamento do sistema brasileiro de controle 
de constitucionalidade. Revista do Advogado, São Paulo, n. 67, ago. 2002.

MEYER-PFLUG, Samantha; ROCHA, Maria Elizabeth Guimarães Teixeira. O controle abstrato nas ações diretas de inconstitucionalidade genérica e interventiva na Constituição brasileira de 1988. In: FÉRES, Marcelo Andrade; CARVALHO, Paulo Gustavo M. (Orgs.). O processo nos Tribunais Superiores. São Paulo: Saraiva, 2006, p. 433-434.

MIRANDA, Jorge. Manual de direito constitucional. Tomo 6, Coimbra: Coimbra Ed., 2008. .. Teoria do estado e da constituição. Rio de Janeiro: Forense, 2002.

MITIDIERO, Daniel; SARLET, Ingo Wolfgang; MARINONI, Luiz Guilherme. Curso de direito constitucional. São Paulo: Revista dos Tribunais, 2012.

MOLLICA, Rogério. Os processos repetitivos e a celeridade processual. 21. Tese (Doutorado em Direito Processual)- Faculdade de Direito, Universidade de São Paulo, São Paulo, 2010.

MORAES, Alexandre de. Direito constitucional. São Paulo: Atlas, 1999.

- Jurisdição constitucional e tribunais constitucionais: garantia suprema da Constituição. São Paulo: Atlas, 2003.

MORAES, Guilherme Peña de. Código de processo constitucional: é necessária a codificação do direito processual constitucional brasileiro? Disponível em: $<$ http://www.cartaforense.com.br/conteudo/artigos/codigo-de-processo-constitucional-enecessaria-a-codificacao-do-direito-processual-constitucional-brasileiro/6980>, desde 03/05/2011. Acesso em: 11 mar. 2014.

Curso de direito constitucional. Niterói: Impetus, 2008.

Justiça constitucional: limites e possibilidades da atividade normativa dos tribunais constitucionais. São Paulo: Atlas, 2012.

MORAIS, Carlos Blanco de. Justiça constitucional. Tomo 2, Coimbra: Coimbra Ed., 2005.

MORAIS, Dalton Santos. Abstrativização do controle difuso de constitucionalidade no Brasil e a participação do amicus curiae em seu processo. Revista de Processo, n. 164, out. /2008.

Críticas à caracterização da atuação senatorial no controle concreto como função de publicidade: a importância da jurisdição ordinária e os limites da mutação constitucional. 
Revista de Processo, n. 176, out./2009, p. 51-92.

MOREIRA, Jairo Cruz. A intervenção do ministério público no processo civil. Belo Horizonte: Del Rey, 2009.

MOREIRA, José Carlos Barbosa. A ação popular do direito brasileiro como instrumento de tutela jurisdicional dos chamados "interesses difusos". Revista de Processo, n. 28, out./dez. 1982.

A constitucionalização do processo no direito brasileiro. In: MAC-GREGOR, Eduardo Ferrer; LARREA, Arturo Zaldívar Lelo de (Coords.). Estudos de direito processual constitucional: homenagem brasileira a Hector Fix-Zamudio em seus 50 anos como pesquisador do Direito. São Paulo: Malheiros Ed., 2009, p. 47-55.

2006

A emenda constitucional n. 45 e o processo. Revista Forense, v. 102, n. 383, jan./fev.

. Comentários ao código de processo civil. Vol. 5. Rio de Janeiro: Forense, 2006.

El control judicial de la constitucionalidad de las leyes em el Derecho brasileño: un bosquejo. Revista Uruguaya de Derecho Procesal, Montevideo, n. 4, jan./mar. 2000, p. 503510.

Mandado de injunção. Revista de Processo, v. 14, n. 56, out./dez. 1989.

Notas sobre alguns aspectos do processo civil e penal nos países anglo-saxônicos. Temas de direito processual: sétima série. São Paulo: Saraiva, 2001.

Sobre pressupostos processuais. In: Temas de Direito Processual - Quarta Série. São Paulo: Saraiva, 1989.

Súmula, jurisprudência e precedentes: uma escalada e seus riscos. Revista Síntese de Direito Civil e Processual Civil, Porto Alegre, n. 35, mai./jun. 2005, p. 11-12.

Tutela de urgência e efetividade do direito. Revista de Direito da Procuradoria Geral do Estado do Rio de Janeiro, n. 57, 2003.

MORO, Sergio Fernando. Jurisdição constitucional como democracia. São Paulo: Revista dos Tribunais, 2004.

MORTARA, Lodovico. Commentario del códice e delle legi di procedura civile. Milano: F. Vallardi, 1923. 
NERY JUNIOR, Nelson. Boa-fé objetiva e segurança jurídica: eficácia da decisão judicial que altera jurisprudência anterior do mesmo tribunal superior. In: FERRAZ JÚNIOR, Tércio Sampaio; CARRAZZA, Roque Antonio; NERY JUNIOR, Nelson (Orgs.). Efeitos ex nunc e as decisões do STJ. Barueri: Manole, 2008.

Princípios do processo civil na Constituição Federal. São Paulo: Revista dos Tribunais, 2004.

NERY, Rosa Maria de Andrade; NERY JUNIOR, Nelson. Código de processo civil comentado e legislação extravagante. São Paulo: Revista dos Tribunais, 2008.

; _. Código de processo civil comentado e legislação extravagante. São Paulo: Revista dos Tribunais, 2003.

; _. Constituição Federal comentada e legislação constitucional. São Paulo: Revista dos Tribunais, 2009.

; C. Constituição Federal comentada e legislação constitucional. São Paulo:

Revista dos Tribunais, 2013.

NEVES, Daniel Amorim Assumpção. Ações constitucionais. Rio de Janeiro: Forense, São Paulo: Método, 2011.

Tutela antecipada e tutela cautelar. In: ARMELIN, Donaldo (Coord.). Tutelas de urgência e cautelares: estudos em homenagem a Ovídio A Baptista da Silva. São Paulo: Saraiva, 2010.

NOBRE JUNIOR, Edilson Pereira. Fiscalização abstrata de constitucionalidade e medida cautelar. A\&C - Revista de Direito Administrativo e Constitucional, Belo Horizonte, a. 10, n. 41, jul./set. 2010.

NOGUEIRA, Antonio de Padua Soubhie. Modulação dos efeitos das decisões no processo civil. 2013. Tese (Doutorado em Direito Processual Civil)- Faculdade de Direito, Universidade de São Paulo, São Paulo, 2013.

NOVELINO, Marcelo. Manual de direito constitucional. São Paulo: Método, 2014, p. 250-252

NUCCI, Guilherme de Souza. Manual de processo penal e execução penal. São Paulo: Revista dos Tribunais, 2006.

NUNES, Cleucio Santos. Medida cautelar em Ação declaratória de constituicioanalidade de lei ou ato normativo - Inconstitucionalidade da eficácia contra todos e efeito vinculante. 
Revista Dialética de Direito Tributário, n. 56, mai. 2000.

O'BRIEN, David M.. Constitutional law and politics: civil rights and civil liberties, Vol. 2. New York: Norton, 2005.

OLIVEIRA, Bruno Silveira de. Flexibilização do binômio "processo tradicional/processo coletivo": breve análise da presença do indivíduo em processos coletivos. Revista de Processo, v. 35, n.189, nov. 2010.

OLIVEIRA, Carlos Alberto Alvaro de. O juiz e o princípio do contraditório. Revista de Processo, n. 73, jul./set. 1993.

Perfil dogmático da tutela de urgência. Revista Forense, n. 342, abr./jun. 1998.

OLIVEIRA, Swarai Cervone de. Jurisdição voluntária: perspectiva atual à luz da teoria geral e da instrumentalidade do processo civil. Reflexos sobre o âmbito de aplicação da discricionariedade judicial. 2011. Tese (Doutorado em Direito Processual)- Faculdade de Direito - Universidade de São Paulo, São Palo. 2011.

Poderes do juiz nos processos coletivos. In: GAZZOLI, Maria Clara; CIANCI, Mirna, CALMON, Petrônio, QIARTIERI, Rita (Coords.). Em defesa de um novo sistema de processos coletivos - Estudos em homenagem a Ada Pellegrini Grinover. São Paulo: Editora Saraiva, 2010, p. 652-674

PALU, Oswaldo Luiz. Controle de constitucionalidade: conceitos, sistemas e efeitos. 2. ed. São Paulo: Revista dos Tribunais, 2001.

PARENTE, Eduardo. Jurisprudência: da divergência à uniformização. São Paulo: Atlas, 2006.

PASTORE, Délton Esteves. Aspectos processuais da ação direta de inconstitucionalidade. 2007. Dissertação (Mestrado em Direito Processual Civil)- Faculdade de Direito, Universidade de São Paulo, São Paulo, 2007.

PAULO, Vicente; ALEXANDRINO, Marcelo. Controle de constitucionalidade. Rio de Janeiro: Impetus, 2006.

PEGORARO, Lucio. A circulação, a recepção e a hibridação dos modelos de justiça constitucional. Tradução: Maria Auxiliadora Castro e Camargo. Revista de Informação Legislativa, Brasília, n. 165, jan./mar, 2005, p. 59-76. 
PEIXOTO, José Carlos de Matos. Recurso extraordinário. Rio de Janeiro: Freitas Bastos, 1935.

PEREZ, Jesus Gonzalez. Derecho procesal constitucional. Madrid: Civitas Editoriais, 1980.

PFEIFER, Roberto Augusto Castellanos. Mandado de injunção. São Paulo: Altas, 1999.

PICARDI, Nicola. La vocazione del nostro tempo per la giurisdizione. Rivista Trimestrale di Diritto e Procedura Civile, a. LVIII, n. I, Milano, mar. 2004.

PIGNATARI, Alessandra Aparecida Calvoso Gomes. Efeitos processuais no controle judicial de constitucionalidade. 2009. Dissertação (Mestrado em Direito Processual)- Faculdade de Direito, Universidade de São Paulo, São Paulo, 2009.

Eficácia subjetiva das decisões judiciais no controle difuso-incidental de constitucionalidade. Revista da Ajuris, Porto Alegre, n. 125, mar. 2012.

PIMENTA, Paulo Lyrio Roberto. O Controle difuso de constitucionalidade das leis no ordenamento brasileiro: aspectos constitucionais e processuais. São Paulo: Malheiros Ed., 2010.

PINTAÚDE, Gabriel. Da urgência no processo objetivo. In: ARMELIN, Donaldo (Coord.). Tutelas de urgência e cautelares: estudos em homenagem a Ovídio A. Baptista da Silva. São Paulo: Saraiva, 2010.

PINTO, José Guilherme Berman Corrêa. O controle concreto de constitucionalidade na Europa e na América do Norte: um estudo comparado. Direito, Estado e Sociedade, Rio de Janeiro, n. 30, jan./jun. 2007.

PIOVESAN, Flávia. Proteção judicial contra omissões legislativas. 2. ed. São Paulo: Revista dos Tribunais, 2000.

; CHADAD, Maria Cecília Cury. Mandado de injunção: desafios e perspectivas. In: MARTINS, Ives Gandra da Silva; JOBIM, Eduardo. O processo na Constituição. São Paulo: Quartier Latin, 2008, p. 410-419.

PIZZORUSSO, Alessandro. Italian and American models of the judiciary and of judicial review of legislation. A comparison of recent tendencies. The American Journal of Comparative Law, n. 2, v. XXXVIII, 1990.

PONTES DE MIRANDA, Francisco Cavalcanti. Comentários ao código de processo civil. Rio 
de Janeiro: Forense, 1977.

Embargos, prejulgado e revista no direito processual brasileiro. Rio de Janeiro: Editora A. Coelho Branco Filho, 1937.

PORTO, Sérgio Gilberto. A regência constitucional do processo civil brasileiro e a posição de um novo código de processo civil. Revista Síntese - Direito Civil e Processual Civil, n. 72, jul./ago. 2011, p. 64-77.

; PORTO, Guilherme Athayde. Lições sobre teorias do processo civil e constitucional. Porto Alegre: Livraria do Advogado, 2013.

PROBST, Paulo Vitor da Silva. A objetivação do recurso extraordinário. Revista de Processo, n. 197, jul./ 2011.

QUARESMA, Regina. O mandado de injunção e a inconstitucionalidade por omissão: teoria e prática. Rio de Janeiro: Forense, 1995.

RAIS, Diogo. A sociedade e o supremo tribunal federal: o caso das audiências públicas. Belo Horizonte: Fórum, 2012.

RAMOS, Elival da Silva. A inconstitucionalidade das leis: vício e sanção. São Paulo: Saraiva, 1994.

Ativismo judicial: parâmetros dogmáticos. São Paulo: Saraiva, 2010.

Perspectivas de evolução do controle de constitucionalidade no Brasil. 2005. Tese (Professor Titular - Departamento de Direito do Estado - Área de Direito Constitucional)Faculdade de Direito, Universidade de São Paulo, São Paulo, 2005.

RAO, Vicente. O direito e a vida dos direitos. São Paulo: Revista dos Tribnais, 2001.

RÊGO, Bruno Noura de Moraes. Argüição de descumprimento de preceito fundamental. Porto Alegre: Sergio Antonio Fabris Editor, 2003.

RESNICK, Judith. Managerial judges. Harvard Law Review, n. 96, dez. 1982, p. 374-448.

ROCHA, Cármen Lúcia Antunes. Constituição e constitucionalidade. Belo Horizonte: Lê, 1991.

ROCHA, José de Albuquerque. Teoria geral do processo. São Paulo: Atlas, 2007. 
RODRÍGUEZ-PATRÓN, Patricia. La autonomia procesal del Tribunal Constitucional. Madrid, Civitas, 2003.

ROSSI, Júlio César. A causa petendi na ação direta de inconstitucionalidade. Revista Dialética de Direito Processual, n. 25, abr. 2005.

A causa petendi no processo civil. São Paulo: Revista dos Tribunais, 1993.

ROTHENBURG, Walter Claudius. Argüição de descumprimento de preceito fundamental. In: ; TAVARES, André Ramos (Orgs.). Argüição de descumprimento de preceito fundamental: análises à luz da Lei 9.882/99. São Paulo: Atlas, 2001.

RUFFIA, Paolo Biscaretti di. Direito constitucional: instituições de direito público. Tradução: Maria Helena Diniz. São Paulo: Revista dos Tribunais, 1984.

RUGGERI, Antonio. Materiali per uno studio dei limiti al sindacato di costituzionalità sulle leggi (introduzione ad una teoria giuridica della funzione "giurisprudenziale" conseguenziale). Scritti su Giustizia Costituzionale in onore di Vezio Crisafulli. Vol. I. Padova: CEDAM, 1985.

SAGÜÉS, Néstor Pedro. Derecho procesal constitucional: logros y obstáculos. Buenos Aires: Ad Hoc, 2006.

Fórmulas de articulación entre la jurisdicción constitucional y la ordinária em Latinoamerica. El caso de Bolivia. Contribuciones, Buenos Aires, n. 3, a. XIX, set. 2002, p. 131-152.

La jurisdicción constitucional (Magistratura y procesos constitucionales) en la reforma constitucional argentina. Boletin: Comision Andina de Juristas, n. 44, Lima, mar. 1995, p. 36,.

SALDANHA, Jânia Moreira Lopes; ESPÍNDOLA, Ângela Araújo da Silveira. A jurisdição constitucional e o caso da ADIn 3510: do modelo individualista e liberal ao modelo coletivo e democrático de processo. Revista de Processo ,n. 154, dez./2007.

SALLES, Carlos Alberto de. Políticas públicas e processo: a questão da legitimidade nas ações coletivas. São Paulo: Revista dos Tribunais, 2003.

Processo civil de interesse público. In: (Org.). Processo civil e interesse público: o processo como instrumento de defesa social. São Paulo: Revista dos Tribunais, 2003, p. 39-73. 
SANTOS, Ernane Fidelis dos. O controle de constitucionalidade das leis e atos normativos. Revista dos Tribunais, $n^{\circ}$ 661, nov. 1998.

SANTOS, Ramon Ouais. Teoria dos capítulos de sentença à luz das técnicas de jurisdição constitucional. Revista de Processo n. 184, jun./2010.

SARAIVA, Paulo Bonavides; Paulo Lopo. Proposta: código de processo constitucional. Folha de São Paulo. Tendências e debates. 10/01/2010.

SARMENTO, Daniel. A dimensão objetiva dos direitos fundamentais: fragmentos de uma teoria. In: SAMPAIO, José Adércio Leite (Org.). Jurisdição constitucional e direitos fundamentais. Belo Horizonte: Del Rey, 2003.

SATTA, Salvatore. L'Execuzione forzata. Milano: Casa Editrice Dott, 1937.

SCHIAVI, Mauro. Execução no processo do trabalho. 2. ed. São Paulo: LTr, 2010.

SCHLOSSER, Lizelote Minéia; WICKERT, Lisiane Beatriz; LUNARDI, Soraya Regina Gasparetto. A influência dos interesses (subjetivos) no controle abstrato de constitucionalidade. Revista Brasileira de Estudos Constitucionais - RBEC, Belo Horizonte, n. 3, a. 1., p. 4-5, jul./set. 2007.

SCHMITT, Sylvie. La nature objective du contentieux constitutionnel des normes: les exemples français et italien. Revue Français e de Droit Constitutionnel. v. 4, n. 72, 2007.

SEGADO, Francisco Fernandez. La jurisdicción constitucional en España. In: BELAUNDE, García (Coords.). La jurisdicción constitucional en Iberoamerica. Madrid: Dykinson, 1997.

SHAPIRO, David. The legislative injunction: a remedy for unconstitutional legilslative inaction. Yale Journal, n. 99, 1989.

SHIMURA, Sérgio. Tutela coletiva e sua efetividade. São Paulo: Método, 2006.

SICA, Heitor Vitor Mendonça. O direito de defesa no processo civil brasileiro: Um estudo sobre a posição do réu. São Paulo: Atlas, 2011.

Reflexões em torno da teoria geral dos procedimentos especiais. Revista de Processo, n. 208, jun. 2012, p. 66-74. 
Camilo; YARSHELL, Flávio Luiz (Orgs.). 40 anos da teoria geral do processo no Brasil: passado, presente e futuro. São Paulo: Malheiros Ed, 2013.

SILVA, Adailson Lima e. Ação declaratória incidental de inconstitucionalidade. São Paulo: Editora Pilares, 2009.

SILVA, De Plácido e. Vocabulário jurídico. Rio de Janeiro: Forense, 1967.

SILVA, José Afonso da. Curso de direito constitucional positivo. São Paulo: Malheiros Ed., 2003.

Direito urbanístico brasileiro. São Paulo: Revista dos Tribunais, 1981.

El proceso constitucional. In: BUZÁN, Victor (Coord.). Defensa de la constitución. garantismo y controles. Libro en reconocimento al Doctor Germán J. Bidart Campos. Buenos Aires: Ediar, 2003.

SILVA, Ovídio Araujo Baptista da. Curso de processo civil. São Paulo: Revista dos Tribunais, 2001.

Curso de processo civil. Vol. 1. Rio de Janeiro: Forense, 2006.

SIQUEIRA JUNIOR, Paulo Hamilton. Direito processual constitucional. São Paulo: Saraiva, 2006.

SLAIBI FILHO, Nagib. Ação declaratória de constitucionalidade. Rio de Janeiro: Forense, 1994.

Direito constitucional. Rio de Janeiro: Forense, 2004.

SÖHN, Harmut. Die abstrakte normentkontrtolle. In: Bundesverfassungsgericht und Grundsgesetz. Vol. I. Tübingen, 1976.

STEFANELLI, Francesca Romana. La giurisdizione oggettiva, la sua funzione in tema di tutela dei diritti soggettivi incisi da un provvedimento camerale e le differenze rispetto ai processi a contenuto oggettivo. Disponível em: <http://www.rivistagiuridica.it/home/dottrina /6/>. Acesso em: 14 jun. 2013.

STONE, Alec. Governing with judges: constitutional politics in Europe. Oxford: Oxford University Press, 2000. 
Qu'y a-t-il de concret dans le contrôle abstrait aux États-Unis. Revue Française de Droit Constitutionnel, Paris, n. 34, 1998.

STONE, Alec. Qu'y a-t-il de concret dans le contrôle abstrait aux États-Unis. Revue Française de Droit Constitutionnel, Paris, n. 34, 1998.

STRECK, Lênio Luiz. Jurisdição constitucional e hermenêutica: uma nova crítica do direito. Porto Alegre: Livraria do Advogado, 2002.

Limites subjetivos da eficácia da sentença e da coisa julgada civil. São Paulo: Revista dos Tribunais, 2006.

O STJ e a desistência recursal. Publicado em 01/2009. Disponível em: <http://jus.com.br/artigos/12173/o-stj-e-a-desistencia-de-recurso>. Acesso em: 16 mai. 2014.

TALAMINI, Eduardo. Arguição de descumprimento de preceito fundamental: função e estrutura. In: FUX, Luiz; NERY JUNIOR, Nelson; WAMBIER, Teresa Arruda Alvim (Coord.). Processo e constituição: estudos em homenagem ao Professor José Carlos Barbosa Moreira. São Paulo: Revista dos Tribunais, 2006, itens 2.2 e 4.

Coisa julgada e sua revisão. São Paulo: Revista dos Tribunais, 2005.

Novos aspectos da jurisdição constitucional brasileira: repercussão geral, força vinculante, modulação dos efeitos do controle de constitucionalidade e alargamento do objeto do controle direto. 2008. Tese (Livre-Docência do Departamento de Direito Processual - Área de Direito Processual Civil)- Faculdade de Direito, Universidade de São Paulo, São Paulo, 2008 .

TARUFFO, Michele; FERRI, Corrado; COMOGLIO, Luigi Paolo. Lezione sul processo civile, 2. ed., Bologna: Il mulino, 1998.

TARZIA, Giuseppe. Medidas cautelares atípicas (uma análise comparativa). Revista de Processo n. 99, jul./set. 2000.

TAVARES, André Ramos. A nova lei de intervenção federal. Jornal Carta Forense. 12/02/2012. Disponível em: <http://www.cartaforense.com.br/conteudo/colunas/a-nova-leide-intervencao-federal/8287> Acesso em: 20 out. 2013.

A repercussão geral no recurso extraordinário. In: TAVARES, André Ramos; LENZA, Pedro; LORA ALARCÓN, Pietro de Jesús (Coords.). Reforma do Judiciário: analisada e comentada. São Paulo: Método, 2005. 
A repercussão geral no recurso extraordinário. In: TAVARES, André Ramos (Coord.). Reforma do judiciário: analisada e comentada. São Paulo: Método, 2005.

A Vocação contemporânea para a constitucionalização do direito: alguns aspectos da constitucionalização como suporte interpretativo das leis e códigos - o caso da interpretação conforme a constituição. Revista Brasileira de Direito Constitucional, n. 7, jan./jun. 2006.

. Justiça constitucional: superando as teses do "legislador negativo" e do ativismo de caráter jurisdicional. In: MAC-GREGOR, Eduardo Ferrer; LELO DE LARREA, Arturo Zaldívar. Estudos de Direito Processual Constitucional: homenagem a Héctor Fix-Zamudio em seus 50 anos como pesquisador do direito. São Paulo: Malheiros Ed., 2009.

. Nova lei da súmula vinculante: estudos e comentários à Lei 11.417, de 19.12.2006. São Paulo: Método, 2007.

Processo "objetivo" como processo aberto ao concreto. Revista Brasileira de Estudos Constitucionais - RBEC, Belo Horizonte, n. 4, 2011.

Recurso extraordinário: modificações, perspectiva e proposta. In: DINAMARCO, Pedro; COSTA, Hélio Rubens; RIBEIRO, José Horácio (Coords.). Linhas mestras do processo civil. São Paulo: Atlas, 2004.

Teoria da justiça constitucional. 2003. Tese (Livre-Docência do Departamento de Direito do Estado - Área de Direito Constitucional)- Faculdade de Direito, Universidade de São Paulo, São Paulo, 2003.

Teoria da justiça constitucional. São Paulo: Saraiva, 2005.

2001. . Tratado da argüição de descumprimento de preceito fundamental. São Paulo: Saraiva, Tribunal constitucional e jurisdição constitucional. São Paulo: Celso Bastos Editor, 1998.

; BELAUNDE, Domingo Garcia. Mais um código? Folha de São Paulo. Tendências e debates. 21/02/2010. Disponível em: <http://www1.folha.uol.com.br/fsp/opiniao/fz 2102201009.htm>. Acesso em: 22 out. 2013.

TELLES JUNIOR, Goffredo. O direito quântico. São Paulo: Max Limonad, 1980.

TEMER, Michel. Elementos de direito constitucional. São Paulo: Malheiros Ed., 1994. 
TESHEINER, José Maria. Ação popular, substituição processual e tutela do direito subjetivo. Revista de Processo, n. 167, jun. 2009, p. 298-404.

Elementos para uma teoria geral do processo. São Paulo: Saraiva, 1993.

Jurisdição e direito objetivo. Revista Justiça do Trabalho, Porto Alegre, n. 325, jan. 2011, p. 28-36.

Relações jurídicas, processo e direito objetivo. Interesse Público, Porto Alegre, n. 67, mai/jun. 2011, p. 141-149.

THEODORO JÚNIOR, Humberto. Curso de direito processual civil. Vol. 1. Rio de Janeiro: Forense, 2003.

Tutela antecipada. Evolução. Visão comparatista. Direito brasileiro e direito europeu. Revista de Processo, n. 157, mar. 2008.

TOMMASEO, Ferruccio. Appunti di diritto processuale civile. Torino: G. Giappicchelli, 1984. 1983.

I processi a contenuti oggettivvi. In: Studi in onore di Enrico Allorio. Milano: Giuffrè,

TORNAGHI, Helio. Comentários ao código de processo civil. São Paulo: Revista dos Tribunais, 1976.

TREMPS, Pablo Pérez. El recurso de amparo. Valencia: Tirant Lo Blanch, 2004, p. 29-32. 1985

Tribunal constitucional y poder judicial. Madrid: Centro de Estudios Constitucionales,

TRIBE, Laurence H.. American constitutional law. New York: Foundation Press, 2000.

Constitutional choices. Cambridge: Harvard University Press, 1985.

TUCCI, Rogério Lauria. Teoria do direito processual penal. São Paulo: Revista dos Tribunais, 2002. 1989.

; CRUZ E TUCCI, José Rogério. Constituição de 1988 e processo. São Paulo: Saraiva, 
VANOSSI, Jorge Reinaldo A.. Teoria constitucional: supremacia y control de constitucionalidad. Buenos Aires: Depalma, 1976.

VELlOSO, Carlos Mario da Silva. A jurisdição constitucional, especialmente do controle concentrado e a repercussão de suas decisões no campo tributário. Revista Fórum de Direito Tributário, Belo Horizonte, n. 58, jul./ago. 2012.

- O Supremo Tribunal Federal, corte constitucional (uma proposta que visa a tornar efetiva a sua missão precípua de guarda da Constituição. Revista de Direito Administrativo, v. 192, abr./jun. 2003, p. 1-27.

VELOSO, Zeno. Controle jurisdicional de constitucionalidade. Belo Horizonte: Del Rey, 2000.

VENTURI, Elton. Apontamentos sobre o processo coletivo, o acesso à justiça e o devido processo social. Gênesis - Revista de Direito Processual, n. 4, jan./jun. 1997, p. 30-31.

VENTURI, Elton. Processo civil coletivo: a tutela jurisdicional dos direitos difusos, coletivos e individuais homogêneos no Brasil - Perspectivas de um Código Brasileiro de Processo Coletivos. São Paulo: Malheiros Ed., 2007.

VIDIGAL, Luis Eulálio de Bueno. Direito processual civil. São Paulo: Saraiva, 1965.

VIEIRA, Oscar Vilhena. Supremocracia. Revista Direito GV, n. 8, mar. 2009.

VITAL, Domingos Fèzas. Garantias jurisdicionais da legalidade na administração pública: França, Inglaterra, Estados Unidos, Bélgica, Alemanha, Itália, Suíça, Espanha e Brasil. Universidade de Coimbra: Coimbra, 1938.

VORONOFF, Alice. Ativismo judicial e democracia: reflexões em torno do mandado de injunção. Revista de Direito da Procuradoria Geral, Rio de Janeiro. n. 66, 2011, p. 29-49.

WAMBIER, Teresa. Nulidades do processo e da sentença. São Paulo: Revista dos Tribunais, 1998.

WATANABE, Kazuo. Da cognição no processo civil. São Paulo: CEBEPEJ, 1999.

Relação entre demanda coletiva e demandas individuais. In: GRINOVER, Ada Pellegrini; MENDES, Aluisio Gonçalves de Castro; WATANABE, Kazuo (Coords.). Direito processual coletivo e o anteprojeto de código brasileiro de processos coletivos. São Paulo: Revista dos Tribunais, 2007, p. 156-160. 
YARSHELL, Flávio Luiz. Ação rescisória: juízos rescindente e rescisório. São Paulo: Malheiros Ed., 2005.

Antecipação da prova sem o requisito da urgência e direito autônomo à prova. São Paulo: Malheiros Ed., 2009.

É oportuno positivar regras sobre processo empresarial? Disponível em: <http://www.cartaforense.com.br/conteudo/colunas/e-oportuno-positivar-regras-sobreprocesso-empresarial/12391>. Acesso em: 16 fev. 2014.

Tutela coletiva e deveres em matéria probatória. In: GAZZOLI, Maria Clara; CIANCI, Mirna, CALMON, Petrônio, QIARTIERI, Rita (Coords.). Em defesa de um novo sistema de processos coletivos: Estudos em homenagem a Ada Pellegrini Grinover. São Paulo: Saraiva, 2010, p. 231-243.

Tutela jurisdicional. São Paulo: Atlas, 1999.

YOSHIKAWA, Eduardo Henrique de Oliveira. A interpretação do direito em tese e a atividade jurisdicional. Revista Dialética de Direito Processual, São Paulo, n. 110, mai. 2012.

ZAGREBELLSKY, Gustavo. Diritto processuale costituzionale? In: CAPPELLETTI, Mauro (Org.). Giudizio "a quo" e promovimento del processo costituzionale. Milano: Giuffrè, 1990.

La giustizia costituzionale. Nuova Edizione. Bologna: Il Mulino, 1989.

Principî e voti: la corte costituzionale e la politica. Torino: G. Einaudi, 2005

Processo costituzionale. Milano: Giuffrè, 1989.

ZAMORA Y CASTILHO, Niceto Alcalá. Proceso, autocomposición y autodefensa: contribuición al estúdio de los fins del proceso. México: Universidad Nacional Autónoma de México, 2000.

ZANOBINI, Guido. Corso di diritto amministrativo. Vol. 2. Milano: Giuffrè, 1946.

ZANZUCHI, Marco Tullio. Diritto processuale civile. Milano: Giuffrè, 1964.

ZAVASCKI, Teori Albino. Antecipação da tutela. São Paulo: Saraiva, 2009.

. Eficácia das sentenças na jurisdição constitucional. São Paulo: Revista dos Tribunais, 
2001.

Processo coletivo: tutela de direitos coletivos e tutela coletiva de direitos. São Paulo: Revista dos Tribunais, 2006.

ZUFELATO, Camilo. Coisa julgada coletiva. 2008. Tese (Doutorado em Direito Processual Civil)- Faculdade de Direito, Universidade de São Paulo, São Paulo, 2008.

Coisa julgada coletiva. São Paulo: Saraiva, 2011.

Controle judicial de políticas públicas mediante ações coletivas e individuais. In: GRINOVER, Ada Pellegrini; WATANABE, Kazuo (Coords.). Controle jurisdicional de políticas públicas. Rio de Janeiro: Forense, 2011. 


\section{BIBLIOGRAFIA CONSULTADA}

ALVIM, José Manoel de Arruda. A alta função jurisdicional do Superior Tribunal de Justiça no âmbito do recurso especial e a relevância de questões. Revista de Processo, n. 96, out./dez. 1999.

- A declaração concentrada de inconstitucionalidade pelo STF e os limites impostos à ação civil pública e ao código de proteção e defesa do consumidor. In: MAZZEI, Rodrigo; NOLASCO, Rita Dias (Coords.). Processo civil coletivo. São Paulo: Quartier Latin, 2005.

ARENHART, Sérgio Cruz. As ações coletivas e o controle das políticas públicas pelo poder judiciário. In: MAZZEI, Rodrigo; NOLASCO, Rita Dias (Coords.). Processo civil coletivo. São Paulo: Quartier Latin do Brasil, 2005, p. 504-524.

BARBOSA E SILVA, Érica. A fluid recovery no sistema brasileiro e a efetivação dos direitos coletivos. In: SALLES, Carlos Alberto de; SILVA, Solange Teles da; NUSDEO, Ana Maria de Oliveira (Orgs.). Processos coletivos e tutela ambiental. Santos: Universitária Leopoldianum, 2006, p. 83-102.

Cumprimento de sentença em ações coletivas: a execução das obrigações pagar. 2008. Dissertação (Mestrado em Direito Processual Civil)- Faculdade de Direito, Universidade de São Paulo, São Paulo, 2008.

BARROSO, Luís Roberto. Interpretação e aplicação da constituição. São Paulo: Saraiva, 2004.

O controle de constitucionalidade no direito brasileiro. São Paulo: Saraiva, 2006.

BEDAQUE, José Roberto dos Santos. Direito e processo: influência do direito material sobre o processo. São Paulo: Malheiros Ed., 1995.

Efetividade do processo e técnica processual, 2. ed. São Paulo: Malheiros Ed., 2007.

BERMUDES, Sérgio. A reforma do judiciário pela emenda constitucional $n^{o} 45$. Rio de Janeiro: Forense, 2005.

BERNARDES, Juliano Taveira. Novas perspectivas de utilização da ação civil pública e da ação popular no controle concreto de constitucionalidade. Disponível em: <http://www.planalto.gov.br/ccivil_03/revista/Rev_52/Artigos/Art_Juliano.htm>. Acesso em: 11 nov. 2013. 
BUENO, Cassio Scarpinella. As class actions norte-americanas e as ações coletivas brasileiras: pontos para uma reflexão conjunta. Revista de Processo, n. 82, abr./jun. 1996.

BUZAID, Alfredo. Ação declaratória no direito brasileiro. São Paulo: Saraiva, 1986.

CAPPELLETTI ,Mauro. Formações sociais e interesses coletivos diante da justiça civil. Revista de Processo, n. 5, jan./mar. 1977, p. 128-159.

CARVALHO FILHO, José dos Santos. Ação civil pública e declaração incidental de inconstitucionalidade. ADCOAS Informações Jurídicas e Empresariais, Rio de Janeiro, n. 8, ago. 1998.

. Ação civil pública: comentários por artigo. Rio de Janeiro: Lúmen Júris, 1999.

CHIOVENDA, Giuseppe. Instituições de direito processual civil. Vol. 1. São Paulo: Malheiros Ed., 2004.

CINTRA, Antônio Carlos de Araújo; GRINOVER, Ada Pellegrini; DINAMARCO, Cândido Rangel. Teoria geral do processo. São Paulo: Malheiros Ed., 2001.

COLE, Charles D.. Precedente judicial: a experiência americana. Revista de Processo, n. 92, out./dez. 1998.

COMOGLIO, Luigi Paolo. Giurisdizione e processo nel quadro delle garanzie costituzionali. Rivista Trimestrale di Diritto e Procedura Civile, Milano, v. 48, n. 4, dez. 1994.

CRUZ E TUCCI, José Rogério. Anotações sobre a repercussão geral como pressuposto de admissibilidade do recurso extraordinário (Lei 11.418/2006). In: CALDEIRA, Adriano; FREIRA, Rodrigo (Orgs.). Terceira etapa da reforma do Código de Processo Civil: estudos em homenagem ao Ministro José Augusto Delgado. Salvador: Podivm, 2007.

Código do consumidor e processo civil: aspectos polêmicos. Revista do Tribunais, v. 671, set. 1991.

Tempo e processo. São Paulo: Revista dos Tribunais, 1997.

DINAMARCO, Cândido Rangel. A função das cortes supremas na América Latina. Revista Forense, Rio de Janeiro, n. 342, abr./maio 1998.

Decisões vinculantes. Revista de Processo, n. 100, out./dez. 2000. 
Ação civil pública. São Paulo: Saraiva, 2001.

FERREIRA FILHO, Manoel Gonçalves. Comentários à constituição brasileira de 1988. Vol. 2, Vol. 4. São Paulo: Saraiva, 1990.

- Sistema constitucional brasileiro e as recentes inovações no controle de constitucionalidade. Revista Unifieo, Osasco, a. 2, n. 4, jan. 2001.

FIELD, Oliver P.. The effect of an inconstitucional statute. Washington: BeardBooks, 1999.

FINE, Toni M.. O uso do precedente e o papel do princípio do Stare Decisis no sistema legal norte-americano. Revista dos Tribunais, n. 782, dez. 2000.

FRANCIULI NETO, Domingos. Argüição de inconstitucionalidade em recurso especial. Revista de Processo, n. 103, jul./set. 2001.

GIDI, Antônio. Coisa julgada e litispendência em ações coletivas. São Paulo: Saraiva, 1991.

GRINOVER, Ada Pellegrini, et al. Código brasileiro de defesa do consumidor: comentado pelos autores do anteprojeto. 8. ed. Rio de Janeiro: Forense Universitária, 2004.

. Ação rescisória e divergência de interpretação em matéria constitucional. Cadernos de Direito Constitucional e Ciência Política, São Paulo, v. 5, n. 17, out./dez. 1996.

As garantias constitucionais do processo nas ações coletivas. Revista de Processo, $\mathrm{n}$. 43, jul./set. 1986.

Coisa julgada erga omnes, secundum eventum litis e secundum probationem. Revista Forense, n. 380, jul./ago. 2005.

Da class action à ação de classe brasileira: os requisitos de admissibilidade. Revista Forense, n. 352, out./dez. 2000.

O controle difuso da constitucionalidade e a coisa julgada erga omnes da ação coletiva. In: . O processo: estudos e pareceres. São Paulo: DPJ, 2005.

Significado social, político e jurídico da tutela dos interesses difusos. Revista de Processo, v. 97, 2000, p. 9-15. 
HESSE, Konrad. La funcion jurisprudencial y el tribunal constitucional en la ley fundamental de bonn. In: HABERLE, Peter. Estudios sobre la jurisdicción constitucional. Mexico: Editorial Porrúa, 2005.

LASPRO, Oreste Nestor de Souza. A ação e suas condições no processo civil de cognição. In: CRUZ E TUCCI, José Rogério (Org.). Processo civil: estudos em homenagem aos 20 anos de vigência do Código de Processo Civil. São Paulo: Saraiva, 1995. p. 191-208.

Devido processo legal e antecipação dos efeitos da tutela. In: MARINONI, Luiz Guilherme (Coord.). Estudos de direito processual civil, São Paulo: Revista dos Tribunais, 2005. p. 265-275.

LEAL, Roger Stiefelmann. A convergência dos sistemas de controle de constitucionalidade: aspectos processuais e institucionais. Revista de Direito Constitucional e Internacional, São Paulo, v. 14, n. 57, out./dez. 2006.

LEONEL, Ricardo de Barros. A causa petendi nas ações coletivas. In: BEDAQUE, José Roberto dos Santos; TUCCI, José Rogério Cruz e. Causa de pedir e pedido no processo civil (questões polêmicas). São Paulo: Revista dos Tribunais, 2002.

Manual do processo coletivo. São Paulo: Revista dos Tribunais, 2002.

LIEBMAN, Enrico Tullio. Eficácia e autoridade da sentença e outros escritos sobre a coisa julgada. 4. ed. Tradução: Alfredo Buzaid; Benvindo Aires; Ada Pellegrini Grinover. Rio de Janeiro: Forense, 2006.

LUCON, Paulo Henrique dos Santos; GABBAY, Daniela Monteiro; ANDRADE, R. F. Alves; T.. C. Interpretação do pedido e da causa de pedir nas demandas coletivas (Conexão, continência e litispendência). In: LUCON, Paulo Henrique dos Santos (Org.). Tutela coletiva: 20 anos da lei de ação civil pública e do fundo de defesa de direitos difusos, 15 anos do Código de Defesa do Consumidor. São Paulo: Atlas, 2006, p. 184-199.

MANCUSO, Rodolfo de Camargo. Ação popular. 5.ed. São Paulo: Revista dos Tribunais, 2003.

Recurso extraordinário e recurso especial. São Paulo: Revista dos Tribunais, 2006.

MARINONI, Luiz Guilherme. Teoria geral do processo. São Paulo: Revista dos Tribunais, 2008.

MARTINS, Ives Gandra da Silva. Aspectos do controle concentrado de constitucionalidade. Revista do Advogado, São Paulo, n. 73, nov. 2003. 

/mar. 2000.

Eficácia das decisões do Supremo Tribunal Federal. Revista de Processo, n. 97, jan.

MAZZILLI, Hugo Nigro. A defesa dos interesses difusos em juízo: meio ambiente, consumidor, patrimônio cultural, patrimônio público e outros interesses. 13. ed. São Paulo: Saraiva, 2001.

MEDINA, José Miguel Garcia. Liquidação e execução de títulos coletivos. In: GRINOVER, Ada Pellegrini; MENDES, Aluisio Gonçalves de Castro; WATANABE, Kazuo (Coords.). Direito processual coletivo e o anteprojeto de código brasileiro de processos coletivos, São Paulo: Revista dos Tribunais, 2007.

MEIRELLES, Hely Lopes. Mandado de segurança, ação popular, ação civil pública, mandado de injunção, habeas data. São Paulo: Malheiros Ed., 1989.

MELlO, Patrícia Perrone Campos. Precedentes e vinculação: instrumentos do stare decisis e prática constitucional brasileira. Revista de Direito Administrativo, n. 245, jul./set. 2005.

MENDES, Gilmar Ferreira. Efeitos das decisões de inconstitucionalidade: técnicas de decisão em sede de controle de constitucionalidade. Revista Brasileira de Direito Constitucional, n. 5, jan. /jun. 2005.

Eficácia erga omnes das decisões proferidas em sede de controle abstrato no plano estadual. Repertório de Jurisprudência IOB, Caderno 1, out. 2002.

Jurisdição constitucional. 4. ed. São Paulo: Saraiva, 2004.

; MARTINS, Ives Gandra da Silva. Controle concentrado de constitucionalidade: comentários à Lei n. 9.868, de 10-11-1999. São Paulo: Saraiva, 2005.

MESQUITA, José Ignácio Botelho de. As novas tendências do direito processual: uma contribuição para o seu reexame. Revista Forense, Rio de Janeiro, v. 98, n. 361, mai./jun. 2002.

MIRANDA, Jorge. Manual de direito constitucional. Tomo 2, Coimbra: Coimbra Ed., 1988.

MOREIRA, José Carlos Barbosa. Ações coletivas na constituição de 1988. Revista de Processo, n. 16, jan./mar. 1991.

. Efectos de la declaración de la inconstitucionalidad de una ley por el Supremo Tribunal Federal brasileño. In: . Temas de direito processual: oitava série. São Paulo:

Saraiva, 2004. 
Tutela jurisdicional dos interesses coletivos ou difusos. Revista de Processo, n. 39, jul./set. 1985.

NERY, Rosa Maria de Andrade; NERY JUNIOR, Nelson. Constituição Federal comentada. São Paulo: Revista dos Tribunais, 2006.

PISANI, Andrea Proto. Lezioni di diritto processuale civile. Napoli: Jovene, 1999.

PONTES DE MIRANDA, Francisco Cavalcanti. Comentários à Constituição de 1967. Tomo 1, Tomo 3, São Paulo: Revista dos Tribunais, 1974.

. Comentários ao Código de Processo Civil. Tomo 6, Rio de Janeiro: Forense, 1975.

Comentários ao Código de Processo Civil. Tomo 5, Rio de Janeiro: Forense, 1974.

RAMOS, Elival da Silva. O controle de constitucionalidade. In: YARSHELL, Flávio Luiz; MORAES, Maurício Zanoide (Orgs.). Estudos em homenagem à professora Ada Pellegrini Grinover. São Paulo: DPJ Editora, 2005.

RODRIGUES, Marcelo Abelha. A distribuição do ônus da prova no anteprojeto do código brasileiro de processos coletivos. In: GRINOVER, Ada Pellegrini; MENDES, Aluisio Gonçalves de Castro; WATANABE, Kazuo (Coords.). Direito processual coletivo e o anteprojeto de código brasileiro de processos coletivos, São Paulo: Revista dos Tribunais, 2007, p. 244-253.

ROMBOLI, Roberto. El control de constitucionalidad de las leyes en Italia. Teoría y Realidad Constitucional, Madrid, n. 4, 2. sem. 1999.

La tipologia de las decisiones de la Corte Constitucional en el processo sobre la constitucionalidad de las leyes planteado em via incidental. Revista Española de Derecho Constitucional, Madrid, n. 48, set./dez. 1996.

ROSENN, Keith S.. Os efeitos do controle judicial de constitucionalidade nos Estados Unidos, Canadá e América Latina numa perspectiva comparada. Revista de Direito Administrativo, Rio de Janeiro, n. 235, jan./mar. 2004.

SALLES, Carlos Alberto de. Ações coletivas: premissas para comparação com o sistema jurídico norte americano. In: ; SILVA, Solange Teles da; NUSDEO, Ana Maria de Oliveira (Orgs.). Processos coletivos e tutela ambiental. Santos: Universitária Leopoldianum, 2006. 
Execução judicial em matéria ambiental. São Paulo: Revista dos Tribunais, 1998.

. Processo civil de interesse público: uma nova perspectiva metodológica. In: BUENO, Cassio Scarpinella; SUNDFELD, Carlos Ari (Coords.). Direito processual público: a fazenda em juízo. 1. ed. São Paulo: Malheiros Ed., 2000. p. 45-65.

SANCHES, Sidney. Aspectos processuais do controle de constitucionalidade. Revista da Esmape - Escola Superior da Magistratura do Estado de Pernambuco, n. 3, jan./mar. 1997.

SANTIAGO. Myriam Passos. Efeitos da declaração de inconstitucionalidade no tempo e a coisa Julgada em matéria tributária. Revista de Processo, n. 94, abr./jun. 1999.

SCAFF, Fernando Facury. Novas dimensões do controle de constitucionalidade no Brasil: prevalência do concentrado e ocaso do difuso. In: MARTINS, Ives Gandra da Silva; JOBIM, Eduardo (Coords.). O processo na constituição. São Paulo: Quartier Latin do Brasil, 2008.

SEGADO, Francisco Fernandez. La jurisdición constitucional ante el siglo XXI. Anales de la Academia Nacional de Derecho y Ciências Sociales de Córdoba, t. 41, 2002.

SELLERS, Mortimer N. S.. The doctrine of precedent in the United States of America. The American Journal of Comparative Law, Berkeley, v. 54, supp., 2006.

SHIMURA, Sérgio. Efetivação da tutela coletiva ressarcitória. 2004. Tese (Livre-Docência)Faculdade de Direito, Pontifícia Universidade Católica, São Paulo, 2004.

SILVA, José Afonso da. Controle de constitucionalidade: variações sobre o mesmo tema. Interesse Público, Sapucaia do Sul, n. 25, mai./jun. 2004.

SILVA, Paulo Eduardo Alves da. Gerenciamento de processos e cultura da litigância - A experiência do "case management" inglês. In: SALLES, Carlos Alberto de (Coord.). As grandes transformações do processo civil brasileiro - Homenagem ao professor Kazuo Watanabe. São Paulo: Quartier Latin, 2009, p. 635-667.

SIMON, Helmut. La jurisdicción constitucional. In: BENDA, Ernst et al. Manual de derecho constitucional, 2. ed. Tradução: Antonio López Pina. Madrid: Instituto Vasco de Administración Pública e Marcial Pons, 2001, p. 836.

SOARES, Guido Fernando Silva. Common law: introdução ao direito dos EUA. São Paulo: Revista dos Tribunais, 2000.

STRECK, Lênio Luiz. Jurisdição constitucional e hermenêutica. 2. ed. Rio de Janeiro: Forense, 2004. 
TARUFFO, Michele. Observações sobre os modelos processuais de civil law e de common law. Revista de Processo, n. 110, abr./jun. 2003, p. 141-157.

TAVARES, André Ramos. Controle difuso de constitucionalidade nas ações coletivas. Revista Brasileira de Direito Constitucional, São Paulo, n. 1, jan./jun. 2003.

. Curso de direito constitucional. São Paulo: Saraiva, 2005.

. Curso de direito constitucional. São Paulo: Saraiva, 2007.

. Curso de direito constitucional. São Paulo: Saraiva, 2009.

THEODORO JÚNIOR, Humberto. Alguns reflexos da Emenda Constitucional 45, de 08.12.2004, sobre o processo civil. Revista de Processo, n. 124, jun. 2005.

TUCCI, Rogério Lauria. Curso de direito processual civil. Vol. 3. São Paulo: Saraiva, 1989.

VENTURI, Elton. Execução da tutela coletiva. São Paulo: Malheiros Ed., 2000.

VIAL, Pablo Ruiz Tagle. Controle constitucional concentrado y difuso: el uso de una dicotomía ruinosa. Revista de Derecho Publico, n. 61, 1998-1999.

VIGLIAR, José Marcelo Menezes. Ação Civil Pública. 4. ed. São Paulo: Atlas, 1999. 2003.

Interesses individuais homogêneos e seus aspectos polêmicos. São Paulo: Saraiva,

VIGORITI, Vincenzo. Interessi collettivi e processo - la legitimazione ad agire. Milão:Giuffrè, 1979.

WALD, Arnoldo. Usos e abusos da ação civil pública (análise de sua patologia). Revista Forense, Rio de Janeiro, n. 329, jan./mar. 1995.

WATANABE, Kazuo. Processo civil de interesse público. In: SALLES, Carlos Alberto de (Org.). Processo civil e interesse público: o processo como instrumento de defesa social. São Paulo: Revista dos Tribunais, 2003.

Tutela antecipatória e tutela específica das obrigações de fazer e não fazer - artigos 273 e 461, CPC. Revista de Direito do Consumidor, n ${ }^{\circ}$ 19, jul./set. 1996. 
YARSHELL, Flávio Luiz. A reforma do Judiciário e a promessa de "duração razoável do processo". Revista do Advogado, São Paulo, n. 75, abr. 2004.

YEAZELL, Stephen C.. Group litigation and social context: Toward a history of the class action. Columbia Law Review, n. 77, 1977.

ZAGREBELSKY, Gustavo. El derecho dúctil: ley, derechos, justicia. Tradção: Marina Gascón. Madrid: Editorial Trotta, 2005.

ZANETTI JUNIOR, Hermes; DIDIER JUNIOR, Fredie. Curso de direito processual civil. Processo Coletivo. Vol. 4. Salvador: Podium, 2009. 